IFN Working Paper No. 749, 2008

\title{
Political Polarization and the Size of Government
}

Erik Lindqvist and Robert Östling 


\title{
Political Polarization and the Size of Government ${ }^{*}$
}

\author{
Erik Lindqvist $^{* *} \&$ Robert Östling ${ }^{* * *}$
}

August 18, 2009

\begin{abstract}
We study the effect of political polarization on public spending using the dispersion of self-reported political preferences as our measure of polarization. Political polarization is strongly associated with smaller government in democratic countries, but there is no relationship between polarization and the size of government in undemocratic countries. The results are robust to a large set of control variables, including GDP per capita and income inequality.
\end{abstract}

Keywords: Political polarization; social cohesion; size of government; redistribution.

\footnotetext{
* Previous versions of this paper have been published in the authors' dissertations, Lindqvist (2007) and Östling (2008). We would like to thank Alberto Alesina, Martin Bech Holte, Roberta Dessi, Mikael Elinder, Tore Ellingsen, Justina A. V. Fischer, Christina Fong, Ola Granström, Magnus Johannesson, Henrik Jordahl, Ethan Kaplan, Torsten Persson, Daniel N. Posner, Paul Seabright, Jean Tirole, Björn Tyrefors, three anonymous referees and seminar participants at the ENTER Jamboree 2007 in Mannheim, the Research Institute of Industrial Economics (Stockholm), the 2006 Ratio Colloquium for Young Social Scientists, Stockholm School of Economics and Uppsala University for encouragement and valuable comments. We are grateful to Carles Boix, Alexander Downes and Torsten Persson for providing data, to Christina Lönnblad for editorial assistance and to Jan Wallander's and Tom Hedelius' Research Foundation for financial support.

** Research Institute of Industrial Economics (IFN), P.O. Box 55665, SE-102 15 Stockholm, Sweden. E-mail: erik.lindqvist@ifn.se.

${ }^{* * *}$ Institute for International Economic Studies, Stockholm University, SE-106 91 Stockholm, Sweden. E-mail: robert.ostling@iies.su.se
} 


\section{Introduction}

Countries differ widely in the extent to which they rely on the government to allocate resources, goods and services. For example, government consumption in the year 2000 amounted to 34.3 percent of total consumption in Sweden as compared to 17.6 percent in the United States (Gwartney and Lawson 2008). Such large differences in government size are hard to reconcile with the standard political economy model of redistribution (Meltzer and Richard, 1981) where the size of government is determined by the economic interest of the median voter. ${ }^{1}$ However, more recent research in economics and political science has suggested that the size of government is also determined by the dispersion or polarization of political preferences.

For example, Alesina et al. (1999) develop a model in which the median voter's preferred size of government is lower the more polarized are political preferences about the appropriate use of public spending. In sharp contrast, Azzimonti (2009) presents a model in which incumbent governments spend more on public goods the lower is the level of agreement over the focus of public spending. Furthermore, previous theoretical and empirical work have suggested that political polarization in the electorate may affect the ability of the poor to form coalitions for increased redistribution (Fernández and Levy 2008), decrease the general sense of cohesion and altruism in society (e.g. Chen and Kendrick 2002) and lead to polarized governments with parties that are more likely to veto spending proposals (Tsebelis 2002).

Given the many plausible theoretical mechanisms, it is an empirical question whether the overall effect of polarization of political preferences is to decrease or increase the size of government. However, previous empirical work has only used indirect measures of political preferences, such as income and

\footnotetext{
${ }^{1}$ Previous literature has considered many other potential determinants of the size of government. Electoral rules (e.g. Persson and Tabellini 2003, Iversen and Soskice 2006), social insurance (Moene and Wallerstein 2001), country size (Alesina and Wacziarg 1998), and openness to international trade (Rodrik 1998) are just a few examples.
} 
ethnic or religious affiliation. ${ }^{2}$ To the extent that one's political views do not follow straight from economic self-interest or group identification, polarization in terms of income, ethnicity or religious beliefs may not fully capture the true level of political polarization. ${ }^{3}$

In this paper, we derive measures of political polarization based on the electorates' self-reported political preferences. We then test whether these measures can explain differences in the size of government across countries. ${ }^{4}$ Though it is unclear from a theoretical perspective whether the net effect of polarization on the size of government is positive or negative, our measures of political polarization are strongly negatively related to the level of public spending.

Do these relationships reflect a causal effect of polarization on government size? An alternative explanation is that political polarization is itself determined by the size of government. Arguably, if political polarization is merely a response to government policies, the relationship between polarization and government size should be similar irrespective of whether citizens have a say in the political process. On the contrary, we find that the observed relationship between polarization and size of government is only present in countries that rank high in terms of democratic development. For democratic countries, the relationship between polarization and size of government is robust to controlling for a large set of potentially confounding factors, including GDP per capita. The results are

${ }^{2}$ For example, ethnic diversity has been shown to be associated with smaller size and lower quality of government (e.g. Alesina et al 1999, Alesina et al. 2001, Luttmer 2001, Vigdor 2004, Alesina and Zhuravskaya 2008). Another line of research has focused on the polarization of political parties and various economic outcomes (e.g. Cukierman et al. 1992, Svensson 1998, Frye 2002, Alt and Dreyer Lassen 2006).

${ }^{3}$ See Shayo (2009) for a model of how group identification may affect political preferences.

${ }^{4}$ To the best of our knowledge, we are the first to test the effect of polarization on the size of government using direct measures of political preferences. We are not the first, however, to study the dispersion of responses to multiple choice questions at the country level. DiMaggio et al. (1996) use survey data to study changes in dispersion and polarization of attitudes over time. Au (1999) and Au and Cheung (2004) study how variation in job characteristics affects certain social outcomes, such as job satisfaction. There is also a literature within social psychology on the determinants of value consensus (e.g. Shalom and Sagie 2000). See also Gerber and Lewis (2004) who calculated a measure of heterogeneity in voter preferences from voting records and showed that legislators were more constrained by the preferences of the median voter in homogeneous districts. 
also robust to using different measures of polarization and dispersion. We take this as an indication that our results can be interpreted causally.

Figure 1 below shows the correlation between one of our polarization measures (the standard deviation of responses to a question about government vs individual responsibility) and government consumption as a fraction of total consumption for countries that are classified as "weak" or "strong" democracies, respectively. The correlation between polarization and size of government is clearly much stronger for strong democracies. Moreover, Figure 1 shows that the relationship is not driven by extreme values in a few countries.
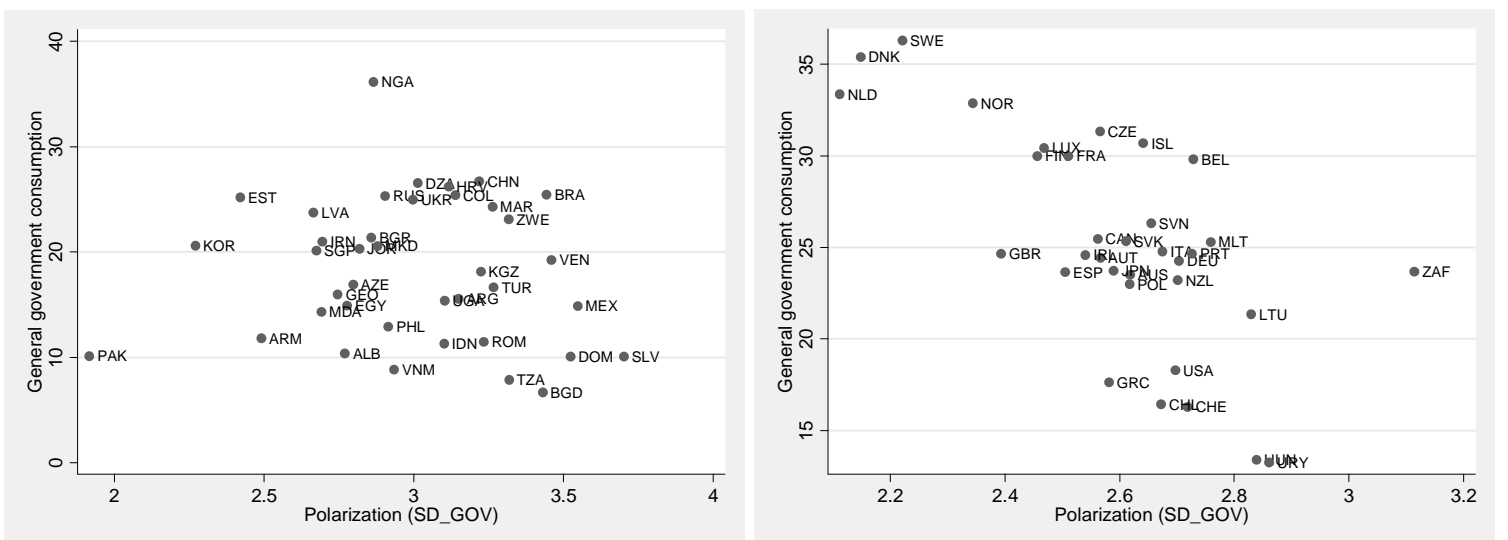

Figure 1. General government consumption and polarization (standard deviation of government responsibility question) in weak (left) and strong (right) democracies.

We also perform tests for specific forms of endogeneity. In particular, government consumption might reduce pre-tax income inequality which reduces distributional conflict. However, our results are robust to controlling for income inequality and using polarization measures that adjust for the distribution of income within countries. Moreover, polarization of political preferences does not seem to be the result of divisive economic policies per se, an unwillingness to give extreme answers in certain countries, or uncertainty about how to answer survey questions.

Although our analysis does not allow us to conclusively distinguish between all possible theoretical mechanisms, we perform a number of tests which indicate that the mechanism that fits the empirical evidence best is the intuition captured by Alesina et al. (1999): Disagreement over how public funds should be spent leads to lower support for government spending. 
Before proceeding to the empirical analysis, the next two sections of the paper discuss the alternative theoretical mechanisms, the data used and how we measure polarization. Data sources and definitions of variables are provided in the Appendix. All empirical results not provided in the text are available online in a Supplementary Appendix. ${ }^{5}$

\section{Theoretical background}

In Meltzer and Richard's (1981) canonical model of redistribution, the size of government is determined by the income of the median voter. Two minor modifications of the model, however, directly imply that dispersion of voter preferences will be related to the size of government.

First, voter turnout is taken as given in Meltzer and Richard's model. However, empirical research indicates that the income of the median voter tends to be above the median income in the population (Bassett et al. 1999). If people with a preference for a large size of government are less likely to vote, the median voter will prefer a smaller size of government than the median opinion in the population. Moreover, the difference between the median voter and in the median in the population will often be larger the higher is the variance of the distribution of preferences. To see this, note that there are typically fewer voters in between two points close to the median (e.g., two different tax rates) the more dispersed are political preferences. ${ }^{6}$

Second, Meltzer and Richard assume that voters vote based on their material self-interest. However, it has been shown that attitudinal similarity is a strong predictor of altruism, attraction and friendship (e.g. Newcomb 1961, Byrne 1961, 1971, Suedfeld et al. 1972, Batson et al. 1981, McGrath 1984, Feren et al. 1988 and Chen and Kendrick 2002) suggesting that political polarization may affect voter

5 The Supplementary Appendix is available at http://swopec.hhs.se/hastef/abs/hastef0628.htm and http://www.ifn.se/web/749.aspx.

${ }^{6}$ This holds if, for example, voter preferences follow a normal or a uniform distribution. More generally, it holds whenever an increase in dispersion shifts probability mass from the center to the tails. See Landsberger \& Meilijson (1990) for one characterization of such changes in the context of risk measurement. 
altruism. ${ }^{7}$ Depending on the exact shape of the income distribution, a general decrease in altruism could in theory lead to either more or less redistribution. In practice, however, the median voter typically does not gain from redistribution which would imply that lower levels of altruism reduces redistribution and provision of public goods (Bassett et al. 1999).

There are also political economic models that directly address the relationship between polarization and public spending. Alesina et al. (1999) develop a model of two-stage voting where the size of the budget is decided before its composition. Citizens first vote for the amount to spend on a public good and then on the type of public good to provide. As voters in the first stage anticipate the outcome of the second stage, support for spending on the public good is decreasing in the dispersion of preferences over its type.

Fernández and Levy (2008) develop a model with endogenous parties and show how preference diversity among the poor affects their ability to extract resources from the rich. As taste diversity increases from a low level, redistribution becomes increasingly tilted toward special interest groups and general redistribution to the poor goes down. However, at a certain threshold, all special interest coalitions break down and general redistribution to the poor increases. Fernández and Levy's (2008) model thus predicts a U-shaped relationship between preference heterogeneity and general redistribution.

Both Alesina et al. (1999) and Fernández and Levy (2008) abstract from dynamic aspects of political decision-making. However, following the seminal work by Persson and Svensson (1989) and Alesina and Tabellini (1990), there is a large literature that focuses on the dynamic strategic incentives of incumbent governments. One of the main ideas in this literature is that an incumbent government that is uncertain about whether it will be re-elected has incentives to behave strategically by implementing policies that restrict the choice set of future governments. The more the preferences of the incumbent government depart from the preferences of potential future governments, the more the incumbent will

\footnotetext{
${ }^{7}$ The relationship between attitudinal similarity and altruism can be rationalized in terms of evolutionary psychology; see Hamilton (1964), Tesser (1993), Olson et al. (2001) and Park and Schaller (2005).
} 
try to restrict future governments' choice set. For example, Persson and Svensson (1989) consider a model in which political parties differ in their preferred size of government and show that incumbents will act strategically by incurring debt in order to affect the cost of public spending in future periods. As pointed out by Persson and Svensson (1989) another state variable that incumbents might use to influence future governments is a "public capital stock" that may be required for the production of public goods. For example, spending on public health care could require the existence of patient records and hospital facilities. This implies that polarization of preferences over the size of government may be systematically related to the size of government. ${ }^{8}$ A similar argument is made by Glazer (1989) who shows that incumbent governments tend over-invest in durable public projects if there is disagreement over the focus of public spending, suggesting that political polarization is associated with higher spending. On the other hand, Svensson (1998) shows that governments might under-invest in the protection of property rights in order to restrict future governments' ability to raise taxes, which suggests that the effect of polarization on size of government is negative. Whereas these papers focus on simple two-period models, there is also a more recent literature that study repeated voting in infinite horizon models. For example, Azzimonti (2009) develops a model in which incumbents overspend on the type of public goods that benefit their own constituency and show that public spending is higher the more politicians disagree over the direction of public spending.

Finally, Tsebelis' (2002) veto player theory provides another mechanism through which polarization might affect the size of government. In countries with many political parties in government and where the ideological distance between parties is large, more political decisions are blocked as political parties in government veto proposals they dislike. This implies that there will be fewer changes in government spending, but the theory is ambiguous with respect to the level of government spending.

To sum up, there are several political mechanisms through which polarization in the electorate may affect the size of government. Most of the theories suggest that the effect of polarization is negative

\footnotetext{
${ }^{8}$ The net effect of polarization on size of government may be either positive or negative depending on whether it is easier to build up or destroy the stock of public capital.
} 
(e.g. Alesina et al., 1999, voter turnout, altruism), some that it is positive (e.g. Azzimonti, 2009) whereas others are ambiguous (Fernández and Levy 2008 and Tsebelis, 2002). The theories also differ in the type of issue over which preferences are polarized. Alesina et al. (1999), Svensson (1998), Fernández and Levy (2008) and Azzimonti (2009) focus on polarization over the type of public goods to spend on, while the voter turnout mechanism and some models of dynamic political decision making (e.g. Persson and Svensson, 1989) focus on polarization over the size of government. The relevant issue in case of veto player theory depends on the institutional structure. If veto players can block either proposed changes in the overall budget or specific spending proposals, they could affect the overall size of government. After presenting the main empirical results, we will return to these and some other differences between the different theories in order to distinguish between them empirically.

\section{Data and measurement}

We base our measures of polarization on responses to multiple-choice questions from the World Values Surveys (WVS) (European and World Values Surveys, 2006). We use data from the 2000 wave for most countries, but to increase the sample, data from the 1995 wave is used for some countries. The WVS is based on face-to-face interviews with about 1,000 respondents in 83 different countries, but nine of these countries are not included in our analysis. ${ }^{9}$ The included countries and the year when the survey was carried out are listed in Table A1.

Ideally we would like to use questions that directly concern the composition and size of public spending. Unfortunately, there are no so such questions in the WVS and we have instead used four

\footnotetext{
${ }^{9}$ We excluded three countries (Northern Ireland, Puerto Rico, Taiwan) because they were not included as separate entities in the other data sources, and four other countries (Serbia and Montenegro, Iraq, Belarus, Saudi Arabia) because government size data was unavailable. In addition, we excluded two countries (Israel and India) because fewer response alternatives were used in these countries.
} 
questions that, broadly speaking, measure various economic aspects of left and right on a 1 to 10 scale. ${ }^{10}$ Table 1 displays the wording of each of these questions.

\begin{tabular}{ll}
\hline Table 1. Economic policy questions \\
\hline EQUALITY & $\begin{array}{l}\text { How would you place your views on this scale? } 1 \text { means that you completely agree with the } \\
\text { statement "Incomes should be made more equal" and } 10 \text { means that you completely agree } \\
\text { with the statement "We need larger income differences as incentives". }\end{array}$ \\
PRIVATE & $\begin{array}{l}\text { How would you place your views on this scale? } 1 \text { means that you completely agree with the } \\
\text { statement "Private ownership of business should be increased" and } 10 \text { means that you } \\
\text { completely agree with the statement "Government ownership of business and industry } \\
\text { should be increased". }\end{array}$ \\
GOV & $\begin{array}{l}\text { How would you place your views on this scale? } 1 \text { means that you completely agree with the } \\
\text { statement "People should take more responsibility to provide for themselves" and } 10 \text { means } \\
\text { that you completely agree with the statement "The government should take more } \\
\text { responsibility ensure that everyone is provided for". }\end{array}$ \\
COMP & $\begin{array}{l}\text { How would you place your views on this scale? } 1 \text { means that you completely agree with the } \\
\text { statement "Competition is good. It stimulates people to work hard and develop new ideas" } \\
\text { and } 10 \text { means that you completely agree with the statement "Competition is harmful. It } \\
\text { brings out the worst in people" }\end{array}$
\end{tabular}

The wording of the questions has been slightly abbreviated.

Alesina et al.'s (1999) model provides the clearest guidance as to the appropriate measure of polarization. In their model, public goods provision is decreasing in the median deviation from the median preference for the composition of public goods. ${ }^{11}$ Since this is a very crude measure given that there are only a few discrete responses to the questions in the WVS, we instead focus on the closely related standard deviation (recall that this is the average squared distance to the average). ${ }^{12}$

\footnotetext{
${ }^{10}$ There are other questions in the WVS that might also be relevant, but these four questions satisfy a number of criteria (more than two response alternatives, sufficiently many observations and not too high correlation between the mean and standard deviation) that we used in a previous version of this paper.

${ }^{11}$ The model by Fernández and Levy (2008) calls for a measure of heterogeneity based on the probability that two randomly matched individuals in the population hold the same opinion. However, this measure does not resonate well with multiple-choice questions as it treats " 4 " and " 5 " on a 1 to 10 scale as two groups as distinct as "1" and " 10 ".

${ }^{12}$ A close substitute to the median distance to the median is the average absolute deviation from the average. However, this is practically indistinguishable from the standard deviation with our data; the correlation is 0.992 for the government responsibility question. Two other common measures of dispersion, the mean difference and the variance are also too highly correlated with the standard deviation to be of interest (the correlation for the government responsibility question is 0.982 and 0.996 , respectively).
} 
The standard deviation is a measure of dispersion as much as of polarization. Several theoretical mechanisms, in particular the dynamic political economy models, are more concerned with polarization than dispersion. We therefore also calculate the polarization measure suggested by Esteban and Ray (1994) for three different parameter values. Esteban and Ray's measure of polarization includes a parameter $\alpha$ which, loosely speaking, measures the extent of sensitivity to polarization rather than dispersion. To satisfy their axioms, $\alpha$ must be between zero and approximately 1.6 and we therefore calculate their measure for $\alpha$ equal to $0.5,1.0$ and 1.5. As pointed out in Section 4 of Esteban and Ray's paper, however, their measure is not designed for cases in which individuals in one category also identify with people in the neighboring category. For example, 25 percent of respondents answering "1", 25 percent "2" and the rest 10 " is considered as less polarized than an equal split between " 2 " and " 10 ". However, if people that use the lowest two response alternatives basically have the same political opinion, it can be argued that the first example is more polarized since preferences in this group are closer to the endpoint of the scale. For this reason, we also consider a simple measure of bipolarization: the minimum of the proportion of respondents that answer "1" or “10". ${ }^{13}$

To fix ideas, consider the histogram of responses for the government responsibility (GOV) question in Brazil and Sweden shown in Figure 2. Irrespective of which measure of polarization that is used, Brazil is more polarized than Sweden. For example, the standard deviation is 3.44 in Brazil and 2.22 in Sweden, whereas the measure of bipolarization is 0.23 in Brazil and 0.02 in Sweden. Brazil ranks higher than Sweden based on Esteban and Ray's measure of polarization for all three levels of $\alpha$, but the relative difference between the two countries falls substantially the higher is $\alpha$.

\footnotetext{
${ }^{13}$ Both the standard deviation and Esteban and Ray's polarization measure treat the ordinal scale of responses to multiple-choice questions as an interval scale. Mouw and Sobel (2001) demonstrate that it is possible to measure dispersion without this assumption, but we believe that the cost in terms of difficulties in interpreting the results using their measure is greater than the benefits of using a well-known and simple measure like the standard deviation. As a robustness check, we also use our bipolarization measure that is only based on the ordinal properties of responses.
} 
Brazil

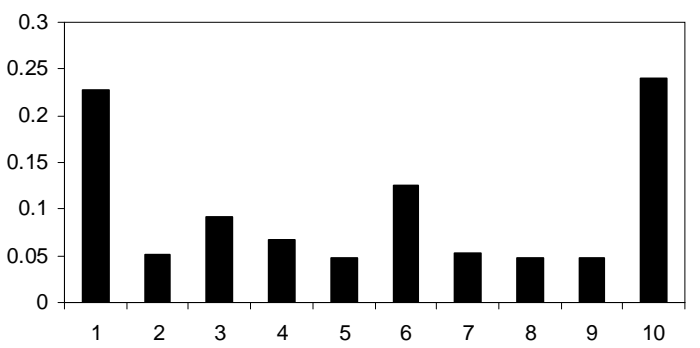

Sweden

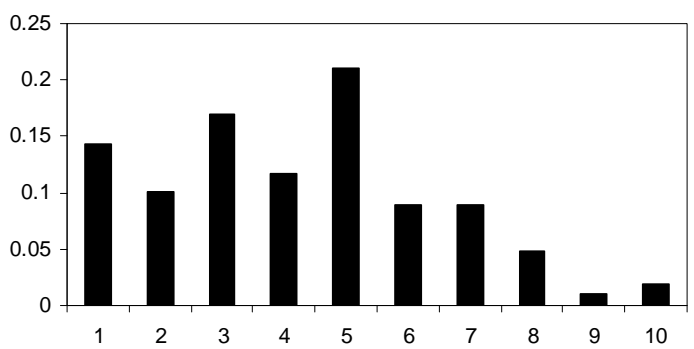

Figure 2. Histogram of responses to GOV question in Brazil and Sweden

\begin{tabular}{lc}
\hline \multicolumn{2}{l}{ Table 2. Correlations with polarization measures (GOV) } \\
\hline Bipolarization & 0.90 \\
Esteban \& Ray $(\alpha=0.5)$ & 0.95 \\
Esteban \& Ray $(\alpha=1.0)$ & 0.80 \\
Esteban \& Ray $(\alpha=1.5)$ & 0.65 \\
\hline
\end{tabular}

Table 2 shows the correlation between the standard deviation and the other polarization measures. Interestingly, Esteban and Ray's measure of polarization is strongly correlated with the standard deviation, but the higher $\alpha$ is, the lower is the correlation. This suggests that we could test whether it is "dispersion" or "polarization" that matter for public spending simply by comparing our results for the standard deviation with those for Esteban and Ray's measure with high $\alpha$. However, as noted above, Esteban and Ray's polarization measure is not ideal for measuring polarization in responses to survey questions. In addition, the distribution of polarization scores becomes more skewed the higher is $\alpha$. To see this, Figure 3 displays histograms of Esteban and Ray's measure for the three different values of $\alpha$. For example, when $\alpha$ is equal to 1.5 , half of the countries are lumped together in a very narrow range. This makes reliable inference difficult. Moreover, our measure of bipolarization is strongly correlated with the standard deviation. This implies that it is difficult to distinguish empirically between "dispersion" and "polarization". In the remainder of the paper, we therefore focus on the standard deviation, but we also report the main results for the other measures listed in Table 2 . 

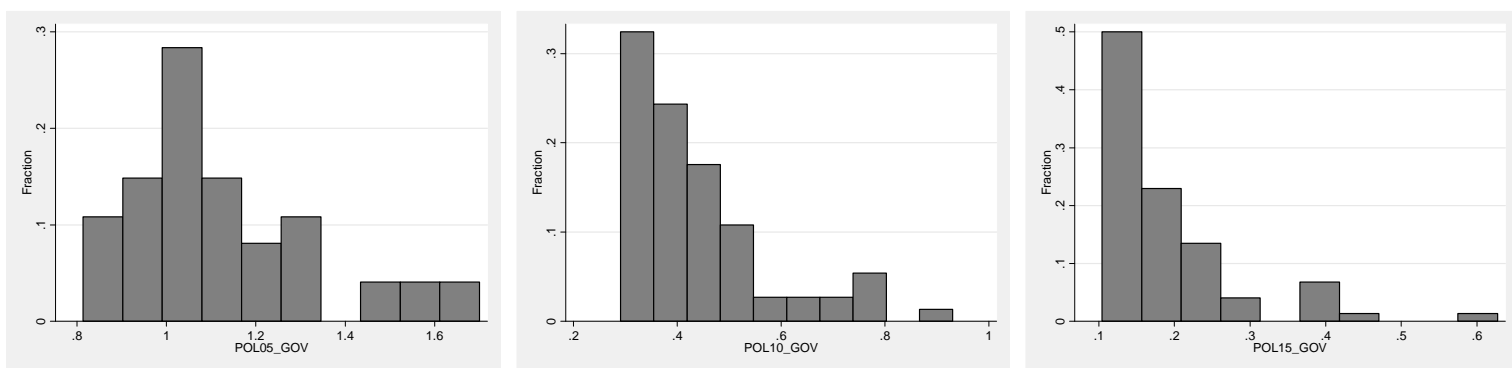

Figure 3. Histogram of Esteban and Ray's polarization measure for the government responsibility question (GOV) for $\alpha=0.5$ (left), $\alpha=1.0$ (center) and $\alpha=1.5$ (right).

As the standard deviation may be correlated with the mean value of responses, we control for the mean in all regressions. ${ }^{14}$ The correlations between mean and standard deviation are low for the economic policy questions. The exception is the question regarding private ownership of business (PRIVATE) where the correlation is $0.44 .{ }^{15}$ However, the mean value need not perfectly reflect the true mean of preferences if responses are centered at either end of the scale (e.g. 1 or 10 on a 1 to 10 scale). For example, consider two countries with continuously normally distributed underlying distributions of preferences with the same mean. If the mean is above 5.5, the country with the highest standard deviation of the underlying distribution will have a lower observable mean since a larger share of respondents have their answers censored at 10 . Hence, the measured standard deviation might be informative about the true mean of preferences even if we control for the measured mean. Similarly, countries with mean values closer to one end point or the other will appear to have a lower standard deviation, since end point censoring reduces variability. In the robustness analysis we control for this by including the absolute deviation from 5.5 as an additional control variable. A related issue is that that three of the questions (EQUALITY, PRIVATE and GOV) refer to the status quo. Yet as long as there is no censoring of responses, this would only affect the mean, but not the standard deviation.

\footnotetext{
${ }^{14}$ The theories reviewed above differ as to whether the mean (or median) should be included as a control variable. We discuss this issue further in the section on causal mechanisms.

15 The correlations between mean value and standard deviation for the other polarization measures are: EQUALITY, -0.17, GOV, 0.13 and COMP, 0.27 .
} 
Although the questions measure different aspects of economic policy, the standard deviations calculated from these questions are strongly correlated. As shown in Table 3, the lowest correlation is 0.66 and the highest 0.86 . The mean values are correlated to a much lower extent; the correlation varies from -0.09 to 0.41 . This suggests that it is much less of a problem that questions are countryspecific when focusing on the dispersion of responses than mean values.

\begin{tabular}{lllll}
\hline \multicolumn{6}{l}{ Table 3. Pairwise correlations of standard deviations } & & \\
\hline & EQUALITY & PRIVATE & GOV & COMP \\
EQUALITY & 1 & & & \\
PRIVATE & 0.73 & 1 & & \\
GOV & 0.70 & 0.86 & 1 & 1 \\
COMP & 0.75 & 0.70 & 0.66 & \\
\hline
\end{tabular}

What characterizes countries with a high or low degree of political polarization? Table 4 lists the ten countries with the highest and lowest standard deviation in the question about government responsibility (GOV). Perhaps surprisingly, Pakistan is the country with the lowest level of political polarization. This is not a peculiarity of this particular question; as shown in Table A1 in the Appendix, Pakistan has a very low standard deviation also for the other economic policy questions. However, Pakistan is also among the countries with the lowest response rates. In the case of the government responsibility question, 37 percent of the respondents in Pakistan said that they did not know or gave no answer at all. ${ }^{16}$ The other countries on the list are less surprising with the Scandinavian countries among the ten most cohesive and five Latin American countries among the most polarized. ${ }^{17}$ Another indication that our measure of polarization captures something essential is

\footnotetext{
${ }^{16}$ The report from the person responsible for collecting WVS data in Pakistan does not reveal anything particular except that certain regions of the country could not be included in the survey for political and security reasons (for example close to the Afghan border). The data from Pakistan may thus not be fully representative.

${ }^{17}$ It should be kept in mind, however, that we cannot readily compare polarization across continents since we only have data from 74 countries. In addition, although WVS contains many developing countries there is a tendency that larger and more developed countries are more likely to be included.
} 
that political polarization is relatively stable over time. The correlation with the standard deviation from the previous wave of the WVS varies between 0.72 and 0.81 for the four questions. ${ }^{18}$

\begin{tabular}{clcclc}
\hline \multicolumn{7}{l}{ Table 4. Countries with the lowest and highest level of political polarization } \\
\hline Rank & Lowest & SD_GOV & Rank & Highest & SD_GOV \\
1 & Pakistan & 1.92 & 65 & Morocco & 3.26 \\
2 & Netherlands & 2.11 & 66 & Turkey & 3.27 \\
3 & Denmark & 2.15 & 67 & Zimbabwe & 3.32 \\
4 & Sweden & 2.22 & 68 & Tanzania & 3.32 \\
5 & South Korea & 2.27 & 69 & Bangladesh & 3.43 \\
6 & Norway & 2.34 & 70 & Brazil & 3.44 \\
7 & Great Britain & 2.39 & 71 & Venezuela & 3.46 \\
8 & Estonia & 2.42 & 72 & Dominican Republic & 3.52 \\
9 & Finland & 2.46 & 73 & Mexico & 3.55 \\
10 & Luxembourg & 2.47 & 74 & El Salvador & 3.70 \\
\hline
\end{tabular}

We now turn to our measures of government size and control variables. We focus on one broad measure of government size, general government consumption as a fraction of total consumption (GOVCONS). This measure has been compiled by Gwartney and Lawson (2008) based on data from the World Bank and the International Monetary Fund. The data refers to an average of the years 2003 to 2005 . This measure captures the extent to which governments rely on political rather than private choice to allocate resources, but it could also reflect whether governments have the fiscal and legal capacity to collect tax revenue. As we will see in the empirical analysis, our results for democratic

\footnotetext{
${ }^{18}$ We base our polarization measures on data from both the 1995 and 2000 waves, but the correlations reported here are based on the correlation with the most recent prior wave, 1990 or 1995, that is available for each country. There is also a 1980 wave of the WVS, but none of the four questions were used in that first wave. Another indication that political polarization is relatively stable over time is that the degrees of political polarization in East and West Germany in 1990, the year of the reunification, are remarkably similar. Ranking all countries by the degree of polarization in 1990, the rank of East and West Germany is 13 and 16 for EQUALITY, 12 and 4 for PRIVATE, 29 and 11 for GOV and 14 and 9 for COMP.
} 
countries are robust also when controlling for GDP per capita, indicating that our results are unlikely to be driven by differences in the capacity to collect tax revenue. We also report the main results using a measure of redistribution, transfers and subsidies as a fraction of GDP (GOVTRANSSUB), which is obtained from the same source as the consumption measure. Naturally, this measure says nothing about the beneficiaries of redistribution. A high share of transfers and subsidies in the economy does not necessarily imply that the government succeeds in redistributing resources from one group to another (e.g. from the rich to the poor). Keeping this caveat in mind, we will nevertheless interpret this as a noisy measure of the level of redistribution. Recall that classical measurement error in the dependent variable only inflates standard errors and does not bias the estimated coefficients.

We use the same basic set of control variables as Persson and Tabellini (2003, Section 3.2.1) in their government size regressions. We divide the Persson and Tabellini controls into two categories: one set of control variables that are likely to be exogenous with respect to both polarization and government size and one set that may be endogenous. The exogenous controls are geographical dummy variables and colonial origin. The regional dummies are Africa (AFRICA), South and East Asia (ASIAE) and Latin and South America and the Carribean (LAAM). The colonial variables indicate British (COL_UKA), Spanish (COL_ESPA) or other colonial origin (COL_OTHA) weighted by years of independence. The variables that may be endogenous are logarithm of GDP per capita in 2000 (LYP), openness to trade in 2000 (TRADE), proportion of population between 15 and 64 (PROP1564) in 2000, proportion of population above 65 in 2000 (PROP65), a dummy variable indicating whether the country has a federal political structure (FEDERAL) and an indicator variable for OECD membership before 1993 with Turkey excluded (OECD). We include a number of additional control variables as robustness checks, but these are described further in connection with the results. All variables are listed and described in Table A2 in the Appendix.

\section{Results}

Let $y_{i}$ denote a measure of government size in country $i$. For each measure $y$, we run the regression

$$
y_{i}=\alpha+\text { Polarization }_{i}+\boldsymbol{X}_{i \boldsymbol{\gamma}}+\varepsilon_{i},
$$


where Polarization $_{i}$ is a measure of polarization in country $i$ and $\boldsymbol{X}_{\boldsymbol{i}}$ is a vector of control variables measured at the country level.

Our econometric analysis proceeds as follows. We first report the results from our basic specifications. We then perform a sensitivity analysis controlling for additional control variables. Finally, we discuss the potential problems due to income inequality and issues of survey data in more detail. In the following section, we discuss different causal mechanisms and try to identify which mechanism has the strongest support in the data. In the main text of the paper, we focus on general government consumption (GOVCONS) as the measure of government size, which is the government size variable available for most countries ( 74 countries), but we also report the main result for transfers and subsidies (GOVTRANSSUB). We focus on the standard deviations for the four economic policy questions (SD_EQUALITY, SD_PRIVATE, SD_GOV and SD_COMP), but we also consider the results for the other polarization measures discussed in the previous section. ${ }^{19}$

We use three different basic specifications for each economic policy question. In the first specification we only include the mean response as a control. In the "short" specification, we include the geographical and colonial controls from Persson \& Tabellini (2003). In the "long" specification, we also include GDP per capita, openness to trade, federal political structure, OECD membership and the two demographic variables. Note that by including GDP per capita in the regressions, we control for one mechanism through which political polarization may affect size of government. ${ }^{20}$

\footnotetext{
${ }^{19}$ We have also considered using an index combining all economic policy questions instead of reporting the results for the four questions separately. We have abstained from doing so for four reasons. First, there would be fewer observations for this index than for any single question. Second, the results for an index would be less straightforward to interpret. Third, comparing the results for four related questions is a sensible first robustness check. Four, it is less straightforward how to control for the mean value when using an index of different questions

${ }^{20}$ For example, Gradstein and Justman (2002) argue that polarization has a negative effect on national income (which, in turn, may affect government size) since it increases transaction costs. Interestingly, the correlations between GDP per capita (LYP) and the polarization measures are strongly negative: -0.28 (SD_EQUALITY), 0.66 (SD_PRIVATE), -0.50 (SD_GOV) and -0.40 (SD_COMP).
} 
In addition to estimating regression (1) on the full sample, we divide the sample according to the level of democratic development. As discussed in the theoretical section, there are several plausible mechanisms for why polarization among voters may affect the size of government. These explanations hinge critically upon government policy responding to voter preferences, which is arguably much more likely to happen in democratic countries. Although political polarization may, in turn, be affected by government policies, it is hard to see why such effects should depend on the level of democratic development. A simple test of a causal effect is therefore to see whether the relationship between polarization and size of government is stronger in more democratic countries. ${ }^{21} \mathrm{We}$ classify the 30 countries with a democracy score (DEMOC) of 9 to 10 as "strong" democracies and the 39 countries with a score of 0 to 8 as "weak" democracies. We choose this particular cut-off in order to get roughly half of the countries in each group. The democracy index is not available for five countries, but we classify three of these countries as strong democracies, giving us a sample of 33 strong democracies in total. ${ }^{22}$

The results from regression (1) for the three different specifications tested on the three samples are shown in Table 5. Political polarization has a negative and statistically significant effect on government consumption in the specifications with controls for the mean response and exogenous set of control variables, but size and significance are reduced in the specification with the endogenous set of control variables. However, the results depend entirely on the level of democratic development. When the sample is restricted to strong democracies, the estimated effect of polarization on government consumption is statistically significant and robust to the different sets of control variables,

\footnotetext{
${ }^{21}$ The test of heterogeneous effects with respect to democracy is only indicative. It is possible, for example, that government spending in democracies fosters homogeneity whereas less democratic countries spend public funds on projects that have no effect on political polarization.

${ }^{22}$ The countries for which data is missing are Bosnia and Herzegovina, Iceland, Luxembourg, Malta and Peru. However, Iceland, Luxembourg and Malta receive the highest possible score on the political and civil rights indices in 2000 published by Freedom House (2005) and, therefore, it seems uncontroversial to classify them as strong democracies. The democracy index is not available for Peru in 2000 since the country was "in transition" with a very low score on the democracy index prior to 2000 and a high score thereafter. Bosnia and Herzegovina was reported "in transition" for the years around 2000.
} 
while it is close to zero and statistically insignificant for the weak democracies. ${ }^{23}$ The implied effect of polarization on public spending in strong democracies is substantial. For example, an increase in SD_GOV by one standard deviation implies a decrease in government consumption as a share of total consumption by 4.0 percentage points. ${ }^{24}$ The effect varies between 2.0 and 6.1 percentage points for the other questions.

An alternative explanation for the stronger relationship between polarization and size of government in strong democracies is that polarization is measured with more error in weak democracies, thus exacerbating attenuation bias. In order to adjust for measurement error, we instrument polarization in weak democracies with polarization from the most recent prior wave of the WVS. The estimates from these regressions are imprecise due to the limited number of observations, but the size of the point estimates do not indicate that the results for weak democracies are due to problems of measurement. ${ }^{25}$

${ }^{23}$ As expected, the results for strong democracies get somewhat weaker, but are generally still statistically significant, when we use more inclusive definitions of strong democracies. The same holds also if we use the classification of democracies proposed by Polity IV based on the Polity score (POLITY). According to this classification, 51 countries are classified as democracies. However, since there are so few countries in the nondemocracy category, it is difficult to make an inference about heterogeneous effects based on this classification.

${ }^{24}$ Note that "standard deviation" here refers to the standard deviation in the distribution of SD_GOV for different countries.

${ }^{25}$ Another indication that the results for weak democracies are unlikely to be driven by measurement error is that restricting the sample of weak democracies to countries with higher response rates, higher levels of literacy or a high correlation between individual question responses does not give systematically different estimates (results available upon request). 


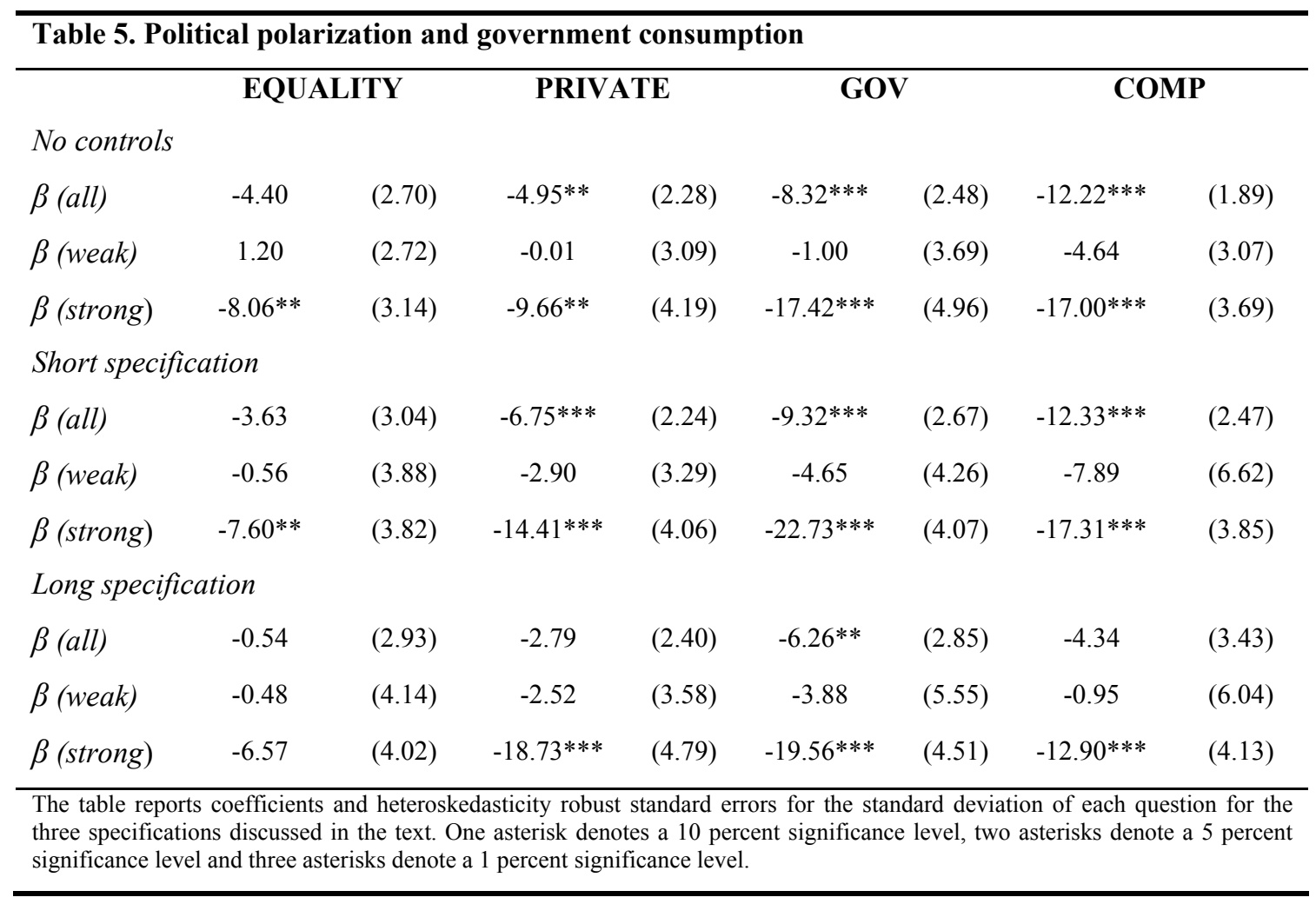

There is a similar pattern when regression (1) is estimated using government transfers and subsidies as the dependent variable instead of government consumption. For strong democracies, political polarization is associated with lower levels of redistribution while there is no relationship between polarization and redistribution in weak democracies. The effect of polarization is not statistically significant in the short specification for strong democracies, but the coefficient estimates are large and statistically significant for three out four cases in the long regression. The reason is that GDP per capita is not controlled for in the short specification. Conditional on the set of exogenous control variables (i.e., the variables in the short specification), richer countries have lower levels of redistribution. As poorer countries are also more polarized on average, not controlling for GDP per capita thus leads to an omitted variable bias toward zero in the short specification.

As the effect of polarization on government consumption is only present in strong democracies, we focus on this subsample for the remainder of the paper. In order to provide a more complete 
description of our results, Table 6 shows the estimated coefficients for all control variables when the sample is restricted to strong democracies. ${ }^{26}$

Table 7 reports the results from further robustness checks where we include additional controls in the long specification. The first set of controls is geographic factors: percent of mountainous terrain, (MOUNTAIN), the logarithm of country $\operatorname{area}^{27}$ (AREA) and absolute distance to the equator (LATITUDE). The second set of controls is additional demographic factors: the logarithm of total population (LOGPOP) and population density (POPDENS). We also include the average level of trust (TRUST) as well as measures of ethnic (ETHFRAC), religious (RELFRAC) and linguistic (LINGFRAC) fractionalization. Finally, we control for a number of political variables that have been found to explain the size of government in previous studies (e.g. Persson and Tabellini 2003): whether the country has a presidential regime (PRES) and whether the legislature is elected under a majoritarian rule (MAJ). Note that we restrict the sample to strong democracies and that the degrees of freedom are small in these regressions, implying that standard errors become large. Overall, the relationship between polarization and size of government remains robust when these additional control variables are included in the regression. It is also worth noting that none of the additional control variables are consistently statistically significant.

We now turn to a discussion of three specific issues: income inequality, the use of survey data and alternative polarization measures.

\footnotetext{
${ }^{26}$ Note that the regressions reported in Table 6 are identical to the regressions for strong democracies in Table 5.

${ }^{27}$ Alesina and Wacziarg (1998) show that smaller countries have a larger share of public consumption of GDP.
} 


\begin{tabular}{|c|c|c|c|c|c|c|c|c|}
\hline & \multicolumn{2}{|c|}{ EQUALITY } & \multicolumn{2}{|c|}{ PRIVATE } & \multicolumn{2}{|c|}{ GOV } & \multicolumn{2}{|c|}{ COMP } \\
\hline \multicolumn{9}{|l|}{ No controls } \\
\hline$\beta$ & $-8.06^{* *}$ & $(3.14)$ & $-9.66 * *$ & $(4.19)$ & $-17.42 * * *$ & $(4.96)$ & $-17.00 * * *$ & (3.69) \\
\hline Mean & 1.44 & $(1.14)$ & 0.86 & $(1.84)$ & -1.20 & $(1.06)$ & $4.35^{* *}$ & $(1.77)$ \\
\hline Adj. $R^{2}$ & \multicolumn{2}{|c|}{0.222} & \multicolumn{2}{|c|}{0.229} & \multicolumn{2}{|c|}{0.460} & \multicolumn{2}{|c|}{0.379} \\
\hline \multicolumn{9}{|c|}{ Short specification } \\
\hline$\beta$ & $-7.60 * *$ & $(3.82)$ & $-14.41 * * *$ & $(4.06)$ & $-22.73 * * *$ & $(4.07)$ & $-17.31 * * *$ & $(3.85)$ \\
\hline Mean & 1.23 & $(1.12)$ & $2.43^{*}$ & $(1.38)$ & -1.14 & $(0.96)$ & $6.86^{* * *}$ & $(1.71)$ \\
\hline AFRICA & -0.23 & $(2.26)$ & 4.16 & $(2.73)$ & $7.83^{* * *}$ & $(1.96)$ & 2.16 & (1.94) \\
\hline ASIAE & - & - & - & - & - & - & - & - \\
\hline LAAM & 3.86 & $(5.89)$ & $8.55^{* * *}$ & $(1.78)$ & $-6.34 *$ & $(3.44)$ & 0.27 & $(2.34)$ \\
\hline COL_ESPA & $-33.16^{*}$ & $(17.63)$ & $-48.05 * * *$ & $(4.29)$ & 14.11 & (11.14) & $-21.53 * * *$ & $(4.47)$ \\
\hline COL_UKA & -1.44 & $(2.97)$ & 1.94 & $(2.30)$ & 2.96 & $(2.65)$ & 1.83 & $(2.47)$ \\
\hline COL_OTHA & $5.66^{*}$ & $(3.06)$ & $7.61 * * *$ & $(1.80)$ & $5.52 * * *$ & $(1.52)$ & $5.56^{* *}$ & $(2.25)$ \\
\hline Adj. $R^{2}$ & \multicolumn{2}{|c|}{0.427} & \multicolumn{2}{|c|}{0.649} & \multicolumn{2}{|c|}{0.639} & \multicolumn{2}{|c|}{0.479} \\
\hline \multicolumn{9}{|c|}{ Long specification } \\
\hline$\beta$ & -6.57 & $(4.02)$ & $-18.73 * * *$ & $(4.79)$ & $-19.56 * * *$ & $(4.51)$ & $-12.90 * * *$ & $(4.13)$ \\
\hline Mean & -0.18 & $(1.80)$ & 1.96 & $(1.76)$ & -1.21 & $(1.31)$ & $4.95^{*}$ & $(2.58)$ \\
\hline AFRICA & 3.42 & $(7.04)$ & 6.09 & $(4.85)$ & $12.65 * * *$ & $(4.87)$ & 0.86 & $(5.28)$ \\
\hline ASIAE & - & - & - & - & - & - & - & - \\
\hline LAAM & -0.50 & $(20.88)$ & 10.16 & (15.08) & $23.98 * *$ & (11.66) & 12.80 & $(16.41)$ \\
\hline COL_ESPA & 0.26 & $(65.50)$ & -48.48 & (67.16) & $-80.02 * *$ & $(36.24)$ & -71.98 & (48.58) \\
\hline COL_UKA & -1.45 & $(4.87)$ & -0.68 & $(3.77)$ & $7.20 * *$ & $(3.00)$ & 1.64 & $(4.78)$ \\
\hline COL_OTHA & 7.95 & $(6.16)$ & $7.05^{*}$ & $(4.04)$ & $7.90 * * *$ & $(2.62)$ & 5.90 & $(4.37)$ \\
\hline LYP & -2.36 & $(3.60)$ & -4.81 & $(2.97)$ & 1.78 & (2.09) & 2.08 & $(2.80)$ \\
\hline TRADE & $0.02 *$ & $(0.01)$ & 0.04 & $(0.02)$ & 0.01 & $(0.01)$ & 0.01 & $(0.02)$ \\
\hline PROP1564 & 0.13 & $(1.02)$ & -0.33 & $(0.95)$ & -0.37 & $(0.70)$ & -0.82 & $(0.80)$ \\
\hline PROP65 & 0.05 & $(0.55)$ & 0.11 & $(0.48)$ & 0.86 & $(0.47)$ & 0.14 & $(0.55)$ \\
\hline FEDERAL & -2.95 & $(3.30)$ & 0.97 & $(2.82)$ & -1.53 & $(2.36)$ & -1.35 & $(2.58)$ \\
\hline OECD & 9.67 & $(7.32)$ & 5.03 & $(6.79)$ & -1.41 & $(4.47)$ & -1.58 & (5.33) \\
\hline Adj. $R^{2}$ & \multicolumn{2}{|c|}{0.513} & \multicolumn{2}{|c|}{0.635} & \multicolumn{2}{|c|}{0.669} & \multicolumn{2}{|c|}{0.449} \\
\hline$N$ & \multicolumn{2}{|c|}{25} & \multicolumn{2}{|c|}{24} & \multicolumn{2}{|c|}{33} & \multicolumn{2}{|c|}{33} \\
\hline
\end{tabular}




\begin{tabular}{|c|c|c|c|c|c|c|c|c|}
\hline \multirow[b]{2}{*}{$\beta$} & \multicolumn{2}{|c|}{ EQUALITY } & \multicolumn{2}{|c|}{ PRIVATE } & \multicolumn{2}{|c|}{ GOV } & \multicolumn{2}{|c|}{ COMP } \\
\hline & $-8.55^{* *}$ & $(4.08)$ & $-20.43^{* * *}$ & $(4.87)$ & $-21.39 * * *$ & $(5.92)$ & -8.05 & $(5.89)$ \\
\hline MOUNTAIN & 0.01 & $(0.08)$ & 0.02 & $(0.05)$ & -0.04 & $(0.07)$ & -0.15 & $(0.10)$ \\
\hline LATITUDE & 1.99 & $(13.43)$ & -5.28 & $(9.95)$ & -6.31 & $(10.28)$ & 14.64 & (11.47) \\
\hline AREA & 1.81 & $(1.67)$ & 1.76 & $(1.34)$ & 0.44 & $(0.78)$ & -0.43 & $(1.22)$ \\
\hline$N$ & \multicolumn{2}{|c|}{23} & \multicolumn{2}{|c|}{22} & \multicolumn{2}{|c|}{29} & \multicolumn{2}{|c|}{29} \\
\hline$\beta$ & -5.65 & (4.18) & $-19.42 * * *$ & $(4.93)$ & $-19.80 * * *$ & $(4.45)$ & $-14.65 * * *$ & (5.13) \\
\hline LOGPOP & 0.87 & (1.24) & 0.80 & $(1.15)$ & 0.07 & $(0.76)$ & -0.34 & $(1.53)$ \\
\hline POPDENS & 0.00 & $(0.01)$ & -0.00 & $(0.01)$ & 0.00 & $(0.00)$ & -0.00 & $(0.01)$ \\
\hline$N$ & \multicolumn{2}{|c|}{25} & \multicolumn{2}{|c|}{24} & \multicolumn{2}{|c|}{33} & \multicolumn{2}{|c|}{33} \\
\hline$\beta$ & $-10.21 * * *$ & (3.73) & $-23.28 * * *$ & $(6.01)$ & $-18.95^{* *}$ & $(7.41)$ & -8.99 & $(5.58)$ \\
\hline TRUST & 12.94 & (13.18) & 11.00 & (10.14) & -1.12 & $(8.82)$ & -9.84 & (10.59) \\
\hline$N$ & \multicolumn{2}{|c|}{25} & \multicolumn{2}{|c|}{24} & \multicolumn{2}{|c|}{33} & \multicolumn{2}{|c|}{33} \\
\hline$\beta$ & -4.24 & $(7.80)$ & $-17.08 * *$ & $(7.57)$ & $-16.25^{* *}$ & $(6.71)$ & -11.55 & (7.64) \\
\hline ETHFRAC & -8.71 & $(8.93)$ & -5.23 & $(5.05)$ & -7.14 & $(6.29)$ & -9.055 & $(8.32)$ \\
\hline RELFRAC & 0.70 & (10.79) & -0.90 & $(6.28)$ & -0.99 & $(4.46)$ & -5.86 & $(7.78)$ \\
\hline LINGFRAC & 7.70 & $(10.20)$ & 6.54 & $(7.85)$ & 9.11 & (9.04) & $15.99 * *$ & $(8.08)$ \\
\hline$N$ & \multicolumn{2}{|c|}{25} & \multicolumn{2}{|c|}{24} & \multicolumn{2}{|c|}{33} & \multicolumn{2}{|c|}{33} \\
\hline$\beta$ & -5.47 & $(3.67)$ & $-16.87 * *$ & $(7.58)$ & $-17.25 * * *$ & $(4.36)$ & $-9.20 *$ & $(5.12)$ \\
\hline PRES & $-9.09 * *$ & $(3.66)$ & -5.80 & $(4.30)$ & -2.16 & (1.98) & -3.36 & $(4.10)$ \\
\hline MAJ & -2.28 & $(1.58)$ & -0.07 & $(1.50)$ & -2.54 & $(1.79)$ & -3.69 & $(2.59)$ \\
\hline$N$ & \multicolumn{2}{|c|}{25} & \multicolumn{2}{|c|}{24} & \multicolumn{2}{|c|}{33} & \multicolumn{2}{|c|}{33} \\
\hline$\beta$ & -4.51 & $(4.79)$ & $-17.39 *$ & $(9.95)$ & $-19.49 * *$ & $(8.71)$ & -7.57 & $(6.51)$ \\
\hline GINI & $-0.89 * *$ & $(0.45)$ & -0.52 & $(0.62)$ & -0.16 & $(0.29)$ & $-0.57^{*}$ & $(0.30)$ \\
\hline$N$ & \multicolumn{2}{|c|}{22} & \multicolumn{2}{|c|}{21} & \multicolumn{2}{|c|}{29} & \multicolumn{2}{|c|}{29} \\
\hline
\end{tabular}




\section{Income inequality}

One concern with the estimates reported above is that polarization of political preferences may be a direct consequence of income inequality. ${ }^{28}$ This gives rise to an endogeneity problem if income inequality is in turn affected by the size of government. For example, spending on public schooling for the poor is likely to reduce pre-tax income inequality. The most straightforward way to control for this is to include a measure of income inequality in regression (1). As can be seen from Table 7, including the Gini coefficient in the long specification does not change the coefficients by much, with the competition (COMP) question as the exception. Note, however, that the Gini coefficient is strongly correlated with political polarization. Since polarization is likely to be measured with error, attenuation bias is exacerbated by including the Gini index, so lower estimated effects of polarization should be expected when the Gini index is included. ${ }^{29}$

Another way of controlling for income inequality is to create an "income-adjusted" measure of political polarization. For each country and question, we run a regression of the respondents' answers on the respondents' income. ${ }^{30}$ We then calculate new polarization measures for each country based on the residuals from these regressions. This gives us polarization measures based on political opinions orthogonal to personal income. The income-adjusted polarization measures are highly correlated with the non-adjusted polarization measures; all correlation coefficients are above 0.99. Not surprisingly, re-running the regressions of government performance using the income-adjusted standard deviations

\footnotetext{
${ }^{28}$ Recall that in political economy models like Meltzer and Richard (1981), voters' preferences for redistribution merely reflect their relative position in the distribution of income. Political preferences regarding redistribution will consequently be more dispersed the higher is pre-tax income inequality.

${ }^{29}$ Another problem is that the Gini index is based on consumption data for developing countries. To the extent that government consumption is correlated with redistribution from rich to poor, higher government consumption is therefore likely to reduce the Gini index for developing countries (since it is based on after-tax income). This would imply that Gini index is endogenous with respect to government consumption, thereby spuriously reducing the estimated effect of political polarization.

${ }^{30}$ Income in the WVS is measured on a 1 to 10 scale that is specific to each country. We include each income category as a dummy variable in the regressions.
} 
yields very similar results. The reason for the small differences between the income-adjusted and ordinary polarization measures is the low explanatory power of stated income for political preferences. A potential explanation for this result is that income is measured with error in the WVS. ${ }^{31}$

\section{Survey data}

A key problem in using survey data is that questions may not only capture underlying differences in political preferences. In particular, the dimension of political conflict measured by our economic policy questions could be more salient in some countries than in others. If people do not perceive a question as capturing a relevant dimension of politics, it seems plausible that they give it less thought, or that they are uncertain about their preferences. ${ }^{32}$ We perform two different tests to check whether political polarization is due to respondent's uncertainty about their actual preferences.

First, we include the country response rate as a control variable in regression (1). The idea is that in countries where many people are uncertain about their preferences, more people will also state that they "don't know" what they think or not answer the question at all. As shown in Table 8, the estimated effect of polarization is practically unchanged when the response rate (PROPRESP) to each question is included as a control variable in the long specification.

Second, we calculate the country-level correlations between individuals' responses to the economic policy questions. For each question, we then calculate the country average of the absolute value of the

\footnotetext{
${ }^{31}$ Current income may not be a very good proxy for permanent income. Therefore, we also added educational attainment (on a 1 to 3 scale) as a regressor in the first stage. Educational attainment is measured on a scale from 1 to 3 and these are included as dummy variables in the regressions. This "income-and-education-adjusted" measure of polarization is also highly correlated with our standard measure with all correlation coefficients larger than 0.98 .

${ }^{32}$ It is not clear whether uncertainty about preferences would lead to an upward or downward bias of the measured level of political polarization. For example, a uniform randomization on a 1 to 10 scale implies a standard deviation of 2.63, far from the theoretical maximum of 4.5 (when half of the respondents answers 1 and the other half 10). Alternatively, uncertain respondents may cluster around certain focal values (e.g., "5"), which would give a very low the measured level of polarization. If uncertain respondents instead randomize between extreme values (i.e., "1" and "10"), the measured level of polarization would be very high. It is uncertain a priori which case better represents the behavior of respondents.
} 
correlations with the other questions. This measure (COHERENCE) captures countries" "ideological coherence"- the extent to which responses to the questions follow a certain pattern - and we expect it to be lower the more uncertain people are about their political preferences. ${ }^{33}$ As displayed in Figure 4, political polarization is negatively correlated with ideological coherence in both weak and strong democracies. ${ }^{34}$ That is, the more polarized are opinions a country, the lower is the correlation between responses to different questions. Moreover, ideological coherence is positively correlated with public spending. ${ }^{35}$ However, as shown in Table 8, our results for polarization are robust to controlling for ideological coherence. ${ }^{36}$ Ideological coherence has a positive sign in three out of four regressions, but the coefficients are never statistically significant.
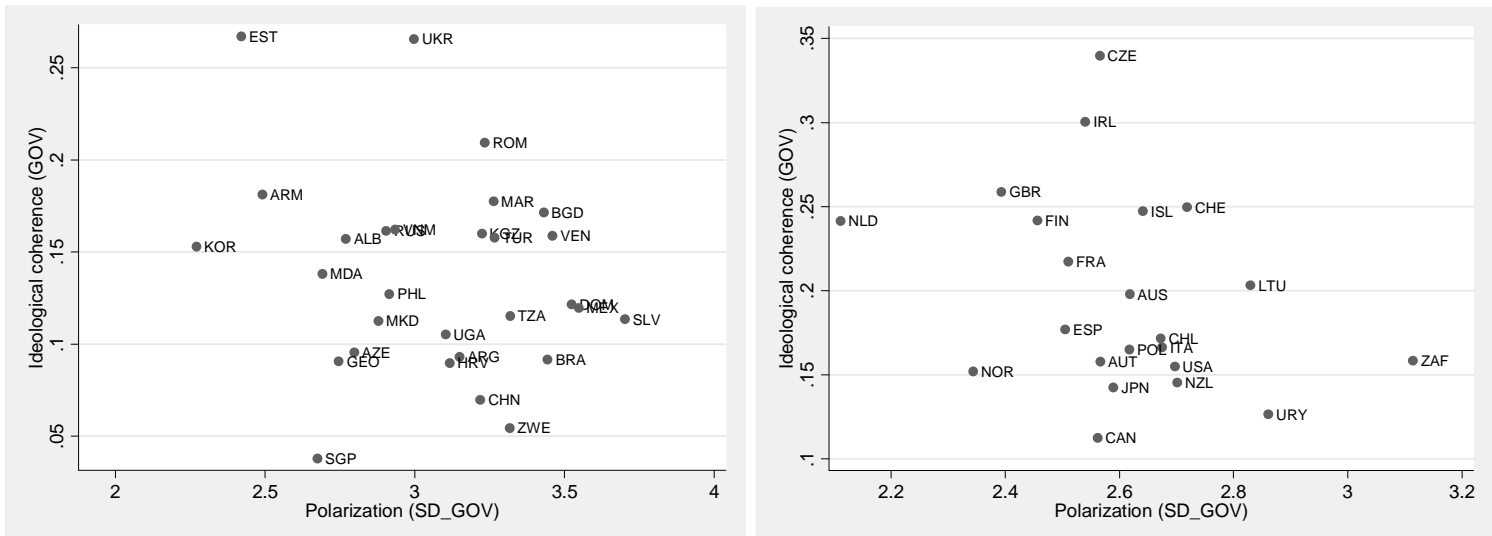

Figure 4. Ideological coherence and polarization in weak (left) and strong (right) democracies based on the government responsibility question.

The result that ideological coherence is higher in countries with a low level of polarization is reassuring in another sense. Since three out of the four questions relate to the current situation in a

\footnotetext{
${ }^{33}$ Our measure of "ideological coherence" is related to a literature in public opinion research on "ideological constraint”. Linzer (Chapter 3, 2008) discusses this literature and proposes new measures.

${ }^{34}$ The correlation coefficients for the four questions vary between -0.19 and -0.38 in weak democracies and between -0.31 and -0.44 in strong democracies.

${ }^{35}$ The correlation coefficients are between 0.39 and 0.53 in strong democracies.

${ }^{36}$ Note that the size of the coefficients for ideological coherence and polarization cannot be directly compared as the scaling of the variables is different.
} 
particular country, another potential concern is that political polarization is a direct effect of the partisanship of policy. For example, suppose that the government in a certain country redistributes income from group X to group Y. If people in this country think of "redistribution" as redistribution from $\mathrm{X}$ to $\mathrm{Y}$, then measured preferences for redistribution may be polarized, even if the preferences are homogenous regarding some other redistribution scheme (say from the rich to the poor). However, as shown above, the estimated effect of polarization on government consumption are similar for all four economic policy questions, implying that partisan policies must shape opinions on all these questions in order to invalidate our argument. The fact that the responses to the economic policy questions are more strongly correlated at the individual level in countries where polarization is low therefore indicates that divisive policies is not a main cause of the measured level of polarization. Moreover, the view that political polarization is a consequence of divisive policies does not fit well with the result that the effect of political polarization is stronger in democracies. ${ }^{37}$

A related concern is that people might be uncertain about the trustworthiness of politicians. Such uncertainty could give rise to an unwillingness to funnel resources to the public sector and, in case people have different beliefs about how trustworthy politicians are, polarization in stated preferences for the size of the public sector. To test this possibility, we include the average response to the WVS question regarding the confidence in parliament (CONFIDENCE) as an additional control variable in regression (1). ${ }^{38}$ We also use the level of corruption (CORRUPTION) within the political system as a proxy for the trustworthiness of politicians. As shown in Table 8, the results change very little from either of these tests.

\footnotetext{
${ }^{37}$ Another form of endogeneity occurs if large governments invest more in policies that foster homogeneity. However, we have not found any evidence in support of this view. For example, there is no indication in our data that political polarization is lower in countries with censorship and lack of a free press. The partial correlations between our measures of polarization and Reporters without borders' index of press freedom (PFREEDOM) range from 0.16 and 0.40 , where a higher score indicates less freedom.

${ }^{38}$ An alternative control variable is the average confidence in government, but this variable is available only for eleven strong democracies.
} 
A final concern with the use of survey data is that people might not want to deviate too much from the opinions of others. A respondent who wants to minimize the maximum deviation from other respondents will answer five or six provided that he does not know the responses of others. If so, countries where people are concerned with consensus would have their responses centered around 5.5. Hence, we include the absolute deviation from 5.5 (CONSENSUS) as a control variable in regression (1) as a rough way of controlling for "false consensus". This is also a rough way of controlling for a correlation between the standard deviation and the true mean of preferences due to censoring of the data, as discussed in the "Data and measurement" section. The results from this robustness check are almost exactly the same as in the basic specifications. Another indication that censoring is quantitatively unimportant is that there is no systematic relationship between the mean values (in terms of left or right) and government size in the basic specification of regression (1) reported in Table 6. 


\begin{tabular}{|c|c|c|c|c|c|c|c|c|}
\hline \multirow[b]{2}{*}{$\beta$} & \multicolumn{2}{|c|}{ EQUALITY } & \multicolumn{2}{|c|}{ PRIVATE } & \multicolumn{2}{|c|}{ GOV } & \multicolumn{2}{|c|}{ COMP } \\
\hline & $-6.47 * *$ & $(2.86)$ & $-15.38 * * *$ & $(4.63)$ & $-18.83^{* * *}$ & $(4.60)$ & $-12.07 * * *$ & $(4.05)$ \\
\hline PROPRESP & $-108.00^{* * *}$ & $(34.08)$ & $-36.07 * *$ & $(14.51)$ & -54.36 & $(58.66)$ & -60.45 & $(41.27)$ \\
\hline$N$ & \multicolumn{2}{|c|}{25} & \multicolumn{2}{|c|}{24} & \multicolumn{2}{|c|}{33} & \multicolumn{2}{|c|}{33} \\
\hline$\beta$ & -4.43 & $(6.23)$ & $-18.54 * * *$ & $(4.55)$ & $-20.77 * * *$ & $(6.82)$ & -11.01 & (7.30) \\
\hline COHERENCE & 25.98 & $(33.57)$ & 18.96 & $(25.77)$ & -16.22 & (19.73) & 2.41 & (20.94) \\
\hline$N$ & \multicolumn{2}{|c|}{22} & \multicolumn{2}{|c|}{22} & \multicolumn{2}{|c|}{22} & \multicolumn{2}{|c|}{22} \\
\hline$\beta$ & $-7.02 *$ & $(3.81)$ & $-19.44 * * *$ & $(4.77)$ & $-18.46^{* * *}$ & $(4.41)$ & $-11.69 * * *$ & $(4.35)$ \\
\hline CONFIDENCE & -6.04 & $(5.46)$ & $-7.04 *$ & $(4.20)$ & -4.34 & $(3.25)$ & -4.94 & (5.34) \\
\hline$N$ & \multicolumn{2}{|c|}{25} & \multicolumn{2}{|c|}{24} & \multicolumn{2}{|c|}{33} & \multicolumn{2}{|c|}{33} \\
\hline$\beta$ & $-8.54 * *$ & $(3.65)$ & $-21.92 * * *$ & $(3.98)$ & $-18.85^{* * *}$ & $(5.41)$ & $-11.43^{* *}$ & (5.06) \\
\hline CORRUPTION & -1.18 & $(1.31)$ & -1.13 & $(0.82)$ & 0.39 & $(0.86)$ & 0.73 & $(0.96)$ \\
\hline$N$ & \multicolumn{2}{|c|}{25} & \multicolumn{2}{|c|}{24} & \multicolumn{2}{|c|}{32} & \multicolumn{2}{|c|}{32} \\
\hline$\beta$ & -6.45 & $(4.30)$ & $-19.23 * * *$ & $(5.22)$ & $-19.48 * * *$ & $(4.53)$ & $-12.90 * * *$ & $(4.13)$ \\
\hline CONSENSUS & -1.64 & $(2.41)$ & 3.42 & $(6.38)$ & -0.41 & $(1.94)$ & $-4.95 *$ & (2.58) \\
\hline$N$ & \multicolumn{2}{|c|}{25} & \multicolumn{2}{|c|}{24} & \multicolumn{2}{|c|}{33} & \multicolumn{2}{|c|}{33} \\
\hline
\end{tabular}

\section{Alternative polarization measures}

As discussed in the "Data and measurement" section, our data does not allow us to distinguish precisely between polarization and dispersion of political preferences. Nevertheless, it is a sensible robustness test to see if our results survive when using alternative measures of polarization. As it turns out, the results change very little when we replace the standard deviation with the polarization measures listed in Table 2 in regression (1). However, the results based on Esteban and Ray’s (1994) measure of polarization are weaker for high $\alpha$. Though this suggests that it is dispersion rather than polarization of political preferences that matter for size of government, we are reluctant to put much 
emphasis on this result due to the skewness of the country level distribution of polarization implied by high $\alpha$ (see Figure 3). ${ }^{39}$

\section{Causal mechanisms}

The empirical analysis in the previous section suggests that there is a negative effect of polarization on the size of government. In this section, we investigate which of the theoretical mechanisms discussed in the theoretical section is most important for this relationship. We will proceed as if we have established that the correlation between polarization and public spending indeed reflects a causal relationship. However, we are aware that some concerns raised above regarding the causal interpretation of the results cannot be ruled out completely. We begin by noting that the theories reviewed in the theoretical section differ in two respects.

First, since we found the net effect of polarization on government consumption to be strongly negative, theories that predict that polarization leads to a larger size of government, like Azzimonti (2009), cannot be the main explanation for our findings.

Second, the models by Alesina et al. (1999), Fernández and Levy (2008) and Azzimonti (2009) focus on polarization over the type of public goods to spend on while polarization over the total amount is what matters in case of the voter turnout mechanism and Persson and Svensson (1989). Unfortunately, the economic policy questions in the WVS capture both preferences for the size of government and composition of public goods. ${ }^{40}$ In order to distinguish between these two types of preferences, we therefore use a principal factor analysis. The underlying idea is that the responses to the four questions depend both on a factor common to all questions and one idiosyncratic term for each question. We interpret the common factor as reflecting a general preference for increasing or decreasing the size of

\footnotetext{
${ }^{39}$ As we have not normalized the units of measurement, the size of the coefficient estimates (reported in the Supplementary Appendix) are not directly comparable across polarization measures.

${ }^{40}$ Ideally, we would like to compute an aggregate measure of each voter's satisfaction with the focus on current spending using questions about many different areas of spending, such as schools, the armed forces, poverty relief, etc.
} 
government while the idiosyncratic terms reflect preferences for a specific type of government intervention. This interpretation is supported by the factor loadings; the common factor has a positive impact on the private ownership (PRIVATE), government responsibility (GOV) and competition (COMP) questions, but a negative loading for the income inequality question (EQUALITY) which has a "reversed" scale. We calculate new polarization measures based on the common factor and the residuals for each question from the factor analysis. As it turns out, the new polarization measure based on the common factor is strongly positively correlated with each of the polarization measures based on the idiosyncratic factors. All these polarization measures are negatively related to government consumption, indicating that polarization over both size of government and composition of public goods matter for size of government. ${ }^{41}$ The polarization measures based upon the question residuals appear to be somewhat more robust as predictors of public spending when both types of measures are added jointly to regression (1). Yet due to the high correlation between these measures and the limited number of degrees of freedom, we are reluctant to put much emphasis on this result. ${ }^{42}$

We now turn to a discussion of specific theoretical mechanisms in order to try to distinguish them empirically.

\section{Altruism}

In contrast to the other theoretical mechanisms, an effect of polarization on size of government via altruism could arise due to polarization in any type of attitude question which respondents consider salient. ${ }^{43}$ We therefore test for this mechanism by comparing the results for polarization in economic policy with the results for polarization using other types of questions. We use five questions that have been deemed particularly important to explain cultural differences in value orientation across time and

\footnotetext{
${ }^{41}$ As data on all four questions is only available for 22 strong democracies, the number of degrees of freedom is low in the long specification, leading to inflated standard errors.

${ }^{42}$ Another complication in interpreting these results is that it is not clear from a theoretical perspective that the relevant variation in the polarization measures should be orthogonal to one another. Hence, including both measures in the same regression is likely to imply overcontrolling.

${ }^{43}$ The relevant issue in case of veto player theory depends on the particular institutional structure.
} 
cultures (Inglehart and Baker, 2000). ${ }^{44}$ The five questions are questions about the importance of god (GOD), strength of national pride (PRIDE), respect for authorities (AUTHORITY) as well as two questions about whether abortion (ABORT) and homosexuality (HOMO) are justifiable. Naturally, the validity of this test hinges upon the assumption that attitudinal similarity in terms of economicpolitical values is not more important for altruism than attitudinal similarity in other domains.

The estimated effects of polarization (in economic policy) remain largely unchanged when the standard deviations and means of these five questions are included in the long specification. The coefficients for polarization in responses to the questions about respect for authorities and attitudes toward homosexuality are positive and insignificant, while the coefficients are negative (and sometimes significant) for polarization based on the other three questions. It is also noteworthy that polarization in all five questions is negatively correlated with polarization in three of the four economic policy questions. For example, recall that Sweden was one of the most cohesive countries with respect to the government responsibility question, whereas Brazil was one of the most polarized. The opposite holds for the question about respect for authorities: Sweden is among the ten most polarized and Brazil among the twenty most cohesive for this measure.

Taken together, these results do not lend much support to the idea that the effect of polarization is due to altruism. The results also indicate that polarization is not one-dimensional, but highly domainspecific.

\section{Voter turnout}

One of the simplest explanations for why political polarization affects size of government is that the decision to vote is correlated with preferences for size of government. If this is true, it would imply two other phenomena. First, we should expect the median respondent in polarized countries to desire an increase in spending (since the decisive voter prefers a lower level of spending than the median

\footnotetext{
${ }^{44}$ Inglehart and Baker lists ten different questions, but we exclude five of these as they concern behavior, are based on an index of other questions or only allow dichotomous responses. We also exclude questions about personal happiness since they do not refer to a preference or a belief.
} 
opinion in the population). Second, the effect of polarization should be dependent upon the level of voter turnout.

Since there is no question that directly captures preferences over the total size of government, we again use a principal factor analysis. We follow the same procedure as above, but exclude the competition question (COMP) from the analysis since that question does not refer to the status quo. Hence, the common factor reflects the preferred change from the status quo size of government. The correlation between the median and standard deviation of the common factor for strong democracies is positive (0.27), indicating that the median voter in polarized countries indeed desires an increase in public spending though the correlation is modest and not statistically significant. However, if polarization affects government size through the non-representativeness of the decisive voter, we should also expect the estimated effect of polarization in the common factor to be sensitive to the inclusion of the median. This is not the case, which casts doubt the importance of the voter turnout mechanism. $^{45}$

Furthermore, we find no evidence in favor of the voter turnout mechanism when we include an interaction term between polarization and voter turnout in parliamentary elections (TURNOUT) in regression $(1){ }^{46}$

\section{Strategic incumbents}

All the dynamic political economy models reviewed in the theoretical section rely on electoral uncertainty. According to these theories, polarization should only matter in countries where re-election probabilities are sufficiently low. To test for this, we include an interaction effect between the majority party's share of the total number of seats in the legislature (MAJSEATS). This interaction term is

${ }^{45}$ The two-stage voting model by Alesina et al. (1999) and altruism-story predict that there should be no correlation between polarization and preferences for changing the status quo level of public spending since, in these models, polarization induces the median voter to desire a smaller size of government.

${ }^{46}$ As we have not normalized the measure of voter turnout around zero, the coefficient estimate for polarization is not comparable to the estimates reported above. 
negative, indicating that the effect of polarization on size of government is larger when the government's re-election probability is high. ${ }^{47}$

More specifically, Svensson (1998) argues that incumbents restrict future governments' opportunity to raise funds by implementing an inefficient legal system. While polarization is the ultimate cause of small government in his model, an inefficient legal system is the proximate cause. We test this aspect of Svensson's model by including a measure of property rights (PRIGHTS) into regression (1). As reported in Table 9, the estimated effect of polarization is not particularly sensitive to controlling for property rights.

\section{Veto players}

We use three different measures from the Database of Political Institutions (Beck et al., 2001) to test for a veto player mechanism: an index of government fractionalization (HERFGOV), an index of fractionalization in the legislature (HERFLEG) and an index of the political polarization of parties in the legislature (GOVPOL). The first two measures are Herfindahl indexes calculated as the sum of the squared seat shares of all parties in the government/legislature and is thus higher the more concentrated is government/legislature to a few large parties. The index of political polarization of parties in the legislature (GOVPOL) is based on an assessment of the ideology of each political party. The polarization index measures the maximum political distance between the ideology of the executive's political party (Left, Center or Right) and the ideologies of the three largest government parties and the largest opposition party.

The estimated effect of polarization should be sensitive to controlling for these measures if the relationship between polarization and size of government were due to a veto player mechanism. Including the three measures in regression (1) leads to somewhat weaker estimated effects of

\footnotetext{
${ }^{47}$ The interaction effect is only statistically significant in the long specification. In the specifications without control variables or with the short set of controls it is close to zero and statistically insignificant. As we have not normalized the share of the majority's seats around zero, the estimated effect of polarization is not directly comparable to the results reported above.
} 
polarization in three out of four regressions, though the effect is not very large. There is also some evidence that government spending is higher the less concentrated is power in parliament to a few large parties. We thus obtain some support in favor of a veto player mechanism.

\section{Coalition formation}

A distinguishing feature of the coalition formation model by Fernández and Levy (2008) is that it is polarization among the poor that is critical for the level of redistribution. Therefore, we calculate two measures of polarization for each country, one based on those that reported a below-median or median income and another for those with an income above the median. As can be seen from Table 9, the results remain qualitatively similar irrespective of which measure is used. Although this casts some doubt on the mechanism suggested by Fernández and Levy (2008), both measures of polarization are highly correlated and it is therefore difficult to estimate the differential impact of polarization among the poor.

To sum up, the theoretical mechanism in our view most consistent with the available evidence is the two-stage voting model by Alesina et al. (1999). This model can explain why the correlation between polarization and public spending is not sensitive to controlling for voter uncertainty, confidence in the political system, or the median respondent's desire to change the status quo level of spending. It is also consistent with the finding that the effect of polarization does not seem to depend on voter turnout or parliamentary majorities, or pertain only to different strata in the population. However, as there is no further test to validate this theory, this is only a tentative conclusion. 


\begin{tabular}{|c|c|c|c|c|c|c|c|c|}
\hline \multirow[b]{2}{*}{$\beta$} & \multicolumn{2}{|c|}{ EQUALITY } & \multicolumn{2}{|c|}{ PRIVATE } & \multicolumn{2}{|c|}{ GOV } & \multicolumn{2}{|c|}{ COMP } \\
\hline & 9.96 & $(33.51)$ & -23.89 & (46.94) & -17.93 & (35.19) & $39.09^{* *}$ & $(17.00)$ \\
\hline$\beta *$ TURNOUT & -21.43 & $(42.71)$ & 6.70 & $(63.87)$ & 0.79 & (42.03) & $-66.82 * * *$ & $(23.38)$ \\
\hline TURNOUT & 66.25 & (123.22) & -11.37 & (144.05) & 9.49 & (109.81) & $162.45^{* * *}$ & $(54.42)$ \\
\hline$N$ & \multicolumn{2}{|c|}{23} & \multicolumn{2}{|c|}{22} & \multicolumn{2}{|c|}{30} & \multicolumn{2}{|c|}{30} \\
\hline$\beta$ & 14.10 & (12.76) & 8.37 & (14.79) & 8.19 & (19.57) & 13.85 & $(13.08)$ \\
\hline$\beta *$ MAJSEATS & $-34.43 *$ & (19.20) & $-43.88 *$ & $(22.71)$ & -47.12 & $(32.20)$ & $-50.97 * *$ & $(25.59)$ \\
\hline MAJSEATS & 83.35 & (50.93) & $92.81 *$ & $(51.91)$ & 112.19 & (84.46) & $104.76^{*}$ & $(59.55)$ \\
\hline$N$ & 25 & 24 & 33 & 33 & 25 & 24 & 33 & 33 \\
\hline$\beta$ & -6.12 & $(4.32)$ & $-18.75^{* * *}$ & (5.79) & $-18.42 * * *$ & $(4.55)$ & $-10.40 * *$ & $(4.29)$ \\
\hline PROPRIGHTS & 0.09 & $(0.16)$ & -0.00 & $(0.19)$ & 0.12 & $(0.12)$ & 0.16 & $(0.12)$ \\
\hline$N$ & \multicolumn{2}{|c|}{25} & \multicolumn{2}{|c|}{24} & \multicolumn{2}{|c|}{33} & \multicolumn{2}{|c|}{33} \\
\hline$\beta$ & -3.58 & (4.36) & -10.01 & $(10.73)$ & $-13.36^{* * *}$ & $(4.25)$ & $-13.50 * * *$ & $(4.03)$ \\
\hline HERFGOV & 10.46 & $(9.52)$ & 5.19 & $(8.35)$ & 6.76 & $(5.15)$ & $16.00 * * *$ & $(5.77)$ \\
\hline HERFLEG & -41.77 & (28.13) & -24.57 & $(34.84)$ & $-28.73^{* *}$ & (14.11) & $-45.25^{* *}$ & (18.08) \\
\hline GOVPOL & 1.20 & (1.53) & 1.09 & $(1.31)$ & 0.85 & $(0.71)$ & 1.76 & (1.09) \\
\hline$N$ & \multicolumn{2}{|c|}{24} & \multicolumn{2}{|c|}{23} & \multicolumn{2}{|c|}{31} & \multicolumn{2}{|c|}{31} \\
\hline$\beta$ (poor) & -5.62 & (4.14) & $-15.63 * * *$ & $(4.08)$ & $-18.78 * * *$ & $(3.60)$ & $-13.30 * * *$ & $(3.56)$ \\
\hline$N$ & \multicolumn{2}{|c|}{25} & \multicolumn{2}{|c|}{23} & \multicolumn{2}{|c|}{32} & \multicolumn{2}{|c|}{32} \\
\hline$\beta$ (rich) & $-6.50^{* *}$ & (3.14) & $-23.53 * * *$ & $(6.17)$ & $-23.07 * * *$ & $(4.68)$ & $-12.00 * *$ & $(5.00)$ \\
\hline$N$ & \multicolumn{2}{|c|}{25} & \multicolumn{2}{|c|}{23} & \multicolumn{2}{|c|}{32} & \multicolumn{2}{|c|}{32} \\
\hline
\end{tabular}

\section{Concluding remarks}

This paper has shown that politically polarized democracies have lower levels of public spending. This relationship is robust to a large set of control variables and holds for several different polarization measures. Moreover, we found no evidence that the correlation between political polarization and 
government size is a direct consequence of income inequality, divisive economic policies, false consensus or inability to understand survey questions.

In our view, the theoretical model that is most consistent with the available empirical evidence is the two-stage model by Alesina et al. (1999). We emphasize, however, that this is a tentative conclusion and that a priority for future research is to better identify the underlying causal mechanism. For this purpose, it would probably be interesting to examine if political polarization can explain variation in public spending within countries. A definite test of the causal mechanism, however, requires some kind of exogenous variation in political polarization that does not have an independent effect on the size of government. Unfortunately, it is difficult — if at all possible - to come up with an instrument that affects political polarization, but does not have an effect on government size.

Another area for future research is to better understand the determinants of political polarization, a topic which is beyond the scope of this paper. Previous research presents several interesting avenues for the study of this question. For example, media probably plays a role in shaping political preferences. Bernhardt et al. (2008) develop a model that predicts that profit-maximizing media firms may have an incentive to supply biased news to partisan audiences, and DellaVigna and Kaplan (2007) and Gerber et al. (2006) have empirically shown that biased media actually affects voting behavior. Political polarization could also be due to a divergence in beliefs about the effects of different policies rather than by a conflict of interest or partisanship. Dixit and Weibull (2007) and Acemoglu et al. (2007) have theoretically studied how such polarized beliefs could arise.

\section{References}

Acemoglu, D., Chernozhukov, V. and Yildiz, M. (2007), "Learning and Disagreement in an Uncertain World", unpublished manuscript, Massachusetts Institute of Technology.

Adserà, A., Boix, C. and Payne, M. (2003), "Are You Being Served? Political Accountability and Quality of Government", Journal of Law, Economics \& Organization 19(2), 445-490.

Alesina, A., Baqir, R. and Easterly, W. (1999), "Public Goods and Ethnic Divisions", Quarterly Journal of Economics 115(4), 1167-1199. 
Alesina, A., Devleeschauwer, A., Easterly, W., Kurlat, S. and Wacziarg, R. (2003), "Fractionalization", Journal of Economic Growth 8(2), 155-194.

Alesina, A., Glaeser, E. and Sacerdote, B. (2001), "Why Doesn't the United States Have a EuropeanStyle Welfare State?", Brookings Paper on Economics Activity 2001(2), 187-254.

Alesina, A. and Tabellini, G. (1990), "A Positive Theory of Fiscal Deficits and Government Debt", Review of Economic Studies 57(3), 403-414.

Alesina, A. and Wacziarg, R. (1998), "Openness, Country Size and Government", Journal of Public Economics 69(3), 305-321.

Alesina, A. and Zhuravskaya, E. (2008), "Segregation and the Quality of Government of Countries", NBER Working Paper 14316.

Alt, J. E. and Dreyer Lassen, D. (2006), “Transparency, Political Polarization, and Political Budget Cycles in OECD Countries", American Journal of Political Science 50(3), 530-550.

$\mathrm{Au}$, K. (1999), "Intra-Cultural Variation: Evidence and Implications for International Business", Journal of International Business Studies 30(4), 799-812.

$\mathrm{Au}, \mathrm{K}$. and Cheung, M. (2004), "Intra-cultural Variation and Job Autonomy in 42 Countries", Organization Studies 25(8), 1339-1362.

Azzimonti, M. (2009), "Barriers to Investment in Polarized Societies", unpublished manuscript, University of Texas.

Bassett, W., Burkett, J. and Putterman, L. (1999), "Income Distribution, Government Transfers, and the Problem of Unequal Influence”, European Journal of Political Economy 15(2), 207-228.

Batson, C. D., Duncan, B. D., Ackerman, P., Buckley, T. and Birch, K. (1981), "Is Empathic Emotion a Source of Altruistic Motivation?”, Journal of Personality and Social Psychology 40(2), 290-302.

Beck, T., Clarke, G., Groff, A., Keefer, P. and Walsh, P. (2001), "New Tools in Comparative Political Economy: The Database of Political Institutions", World Bank Economic Review 15(1), 165-176. Data (DPI2006) retrieved from http://go.worldbank.org/2EAGGLRZ40. 
Bernhardt, D. Krasa, S. and Polborn, M. (2008), "Political Polarization and the Electoral Effects of Media Bias", Journal of Public Economics 92(5-6), 1092-1104.

Byrne, D. (1961), "Interpersonal Attraction and Attitude Similarity", Journal of Abnormal Social Psychology 62, 713-715.

Byrne, D. (1971), The Attraction Paradigm, Free Press, New York.

Chen, F. and Kenrick, D. (2002), "Repulsion or Attraction? Group Membership and Assumed Attitude Similarity", Journal of Personality and Social Psychology 83(1), 111-125.

Cukierman, A., Edwards, S., and Tabellini, G. (1992), "Seignorage and Political Instability", American Economic Review 82(3), 537-555.

DellaVigna, S. and Kaplan, E. (2007), “The Fox News Effect: Media Bias and Voting”, Quarterly Journal of Economics 122(3), 1187-1234.

DiMaggio, P., Evans, J. and Bryson, B. (1996), “Have Americans' Social Attitudes Become More Polarized?", American Journal of Sociology 102(3), 690-755.

Dixit, A. and Weibull, J. (2007), "Political Polarization", Proceedings of the National Academy of Sciences 104, 7351-7356.

Esteban, J-M. and Ray, D. (1994), “On the Measurement of Polarization”, Econometrica 62(4), 819851.

European Values Study Group and World Values Association (2006), European and World Values Surveys Four-wave Integrated Data File 1981-2004, version 20060423, downloaded from www.worldvaluessurvey.org.

Fearon, J. and Laitin, D. (2003), "Ethnicity, Insurgency, and Civil War", American Political Science Review 97(1), 75-90.

Feren, D., Carroll, S. and Olian, J. (1988), "Effects of Managerial Performance and Attitudinal Similarity on Interpersonal Attraction", Basic and Applied Social Psychology 9(1), 33-44. 
Fernández, R. and Levy, G. (2008), "Diversity and Redistribution”, Journal of Public Economics 92(5-6), 925-943.

Freedom House (2005), Freedom in the World Country Rankings 1973-2005, Washington, DC. Data retrieved from www.freedomhouse.org.

Frye, T. (2002), "The Perils of Polarization: Economic Performance in the Postcommunist World", World Politics 54(3), 308-337.

Gerber, E. and Lewis, J. (2004), "Beyond the Median: Voter Preferences, District Heterogeneity, and Representation", Journal of Political Economy 112(6), 1364-1383.

Gerber, A., Karlan, D. S. and Bergan, D. (2006), "Does the Media Matter? A Field Experiment Measuring the Effect of Newspapers on Voting Behavior and Political Opinions", Yale Economic Applications and Policy Discussion Paper 12.

Glazer, A. (1989), "Politics and the Choice of Durability", American Economic Review 79(5), $1207-$ 1213.

Gradstein, M. and Justman, M. (2002), "Education, Social Cohesion, and Economic Growth", American Economic Review 92(4), 1192-1204.

Gwartney, J. and Lawson, R. (2008), Economic Freedom of the World: 2008 Annual Report, Fraser Institute, Vancouver. Data retrieved from www.freetheworld.com.

Hamilton, W. D. (1964), “The Genetic Evolution of Social Behaviour”, Journal of Theoretical Biology $7,1-52$.

Inglehart, R. and Baker, W. E. (2000), "Modernization, Cultural Change, and the Persistence of Traditional Values", American Sociological Review 65, 19-51.

Iversen, T. and Soskice, D. (2006), "Electoral Systems and the Politics of Coalitions: Why Some Democracies Redistribute More than Others", American Political Science Review 100(2), 165-181. 
Keefer P. and Stasavage, D. (2003), "The Limits of Delegation: Veto Players, Central Bank Independence and the Credibility of Monetary Policy”, American Political Science Review 97(3), 407423.

Landsberger, M. and Meilijson, I. (1990), "A tale of two tails: An alternative characterization of comparative risk", Journal of Risk and Uncertainty 3(1), 65-82.

La Porta, R., Lopez de Silanes, F., Shleifer, A. and Vishny, R. (1999), “The Quality of Government”, Journal of Law, Economics and Organization 15(1), 222-279.

Lindqvist, E. (2007), Essays on Privatization, Identity and Political Polarization, Ph.D. Thesis, Stockholm School of Economics.

Linzer, D. A. (2008), The Structure of Mass Ideology and its Consequences for Democratic Governance, Ph.D. Thesis, University of California Los Angeles.

Luttmer, E. F. P. (2001), "Group Loyalty and the Taste for Redistribution”, Journal of Political Economy 109(3), 500-528.

Marshall, M. G. and Jaggers K. (2007), Political Regime Characteristics and Transitions 1800-2007, Polity IV Project, University of Maryland. Data retrieved from www.systemicpeace.org/inscr/inscr.htm.

McGrath, J. E. (1984), Groups: Interaction and Process, Prentice-Hall, Englewood Cliffs, NJ.

Meltzer, A. H. and Richard, S. F. (1981), “A Rational Theory of the Size of Government”, Journal of Political Economy 89(5), 914-927.

Moene, K. O. and Wallerstein, M. (2001), "Inequality, Social Insurance, and Redistribution", American Political Science Review 95(4), 859-874.

Mouw, T. and Sobel, M. E. (2001), "Culture Wars and Opinion Polarization: The Case of Abortion", American Journal of Sociology 106(4), 913-943.

Newcomb, T. M. (1961), The Acquaintance Process, Holt, Rinehart \& Winston, New York. 
Olson, J. M., Vernon, P. A. and Jang, K. L. (2001), “The Heritability of Attitudes: A Study of Twins”, Journal of Personality and Social Psychology 80(6), 845-860.

Östling, R. (2008), Bounded Rationality and Endogenous Preferences, Ph.D. Thesis, Stockholm School of Economics.

Park, J. and Schaller, M. (2005), "Does Attitude Similarity Serve As a Heuristic Cue for Kinship? Evidence of an Implicit Cognitive Association", Evolution and Human Behavior 26, 158-170.

Persson, T. and Svensson, L. E. O. (1989), “Why a Stubborn Conservative would Run a Deficit: Policy with Time-Inconsistent Preferences”, Quarterly Journal of Economics 104(2), 325-345.

Persson, T. and Tabellini, G. (2003), The Economic Effects of Constitutions, The MIT Press, Cambridge, MA.

Rodrik, D. (1998), “Why Do More Open Economies Have Bigger Governments?”, Journal of Political Economy 106(5), 997-1032.

Shalom, S. and Sagie, G. (2000), "Value Consensus and Importance", Journal of Cross-Cultural Psychology 31(4), 465-497.

Shayo, M. (2009), “A Model of Social Identity with an Application to Political Economy: Nation, Class, and Redistribution", American Political Science Review 103(2), 147-174.

Suedfeld, P., Bochner, S. and Wnek, D. (1972), "Helper-Sufferer Similarity and a Specific Request for Help: Bystander Intervention During a Peace Demonstration”, Journal of Applied Social Psychology 2 (1), 17-23.

Svensson, J. (1998), "Investment, Property Rights and Political Instability: Theory and Evidence", European Economic Review 42(7), 1317-1341.

Teorell, J, Holmberg, S. and Rothstein, B. (2008), The Quality of Government Dataset, version 15 May 2008, The Quality of Government Institute, University of Gothenburg. Data retrieved from www.qog.pol.gu.se. 
Tesser, A. (1993), “The Importance of Heritability in Psychological Research: The Case of Attitudes”, Psychological Review 100(1), 129-142.

Tsebelis, G. (2002), Veto Players: How Political Institutions Work, Princeton University Press, Princeton, NJ.

Vigdor, J. L. (2004), "Community Composition and Collective Action: Analyzing Initial Mail Response to the 2000 Census", Review of Economics and Statistics 86(1), 303-312.

World Bank (2009), World Development Indicators 2009, Washington, DC. Data retrieved from www.worldbank.org. 


\section{Appendix}

\begin{tabular}{|c|c|c|c|c|c|c|}
\hline Country & Code & Year & $\overline{S D \_E Q U A L I T Y}$ & SD_PRIVATE & SD_GOV & SD_COMP \\
\hline Albania & ALB & 2002 & 2.473 & 2.428 & 2.770 & 2.029 \\
\hline Algeria & DZA & 2002 & 2.572 & 3.194 & 3.014 & \\
\hline Argentina & ARG & 1999 & 3.253 & 3.075 & 3.151 & 3.189 \\
\hline Armenia & ARM & 1997 & 2.779 & 2.845 & 2.491 & 2.538 \\
\hline Australia* & AUS & 1995 & 2.555 & 2.294 & 2.618 & 2.116 \\
\hline Austria* & AUT & 1999 & 2.569 & 2.101 & 2.567 & 2.012 \\
\hline Azerbaijan & AZE & 1997 & 2.921 & 3.010 & 2.798 & 2.551 \\
\hline Bangladesh & BGD & 2002 & 2.855 & 3.351 & 3.432 & 2.474 \\
\hline Belgium* & BEL & 1999 & 2.924 & & 2.729 & 2.604 \\
\hline Bosnia and Herzegovina & $\mathrm{BIH}$ & 2001 & 2.604 & 2.657 & 2.865 & 2.147 \\
\hline Brazil & BRA & 1997 & 3.441 & 3.197 & 3.444 & 2.923 \\
\hline Bulgaria & BGR & 1999 & 3.005 & & 2.858 & 2.465 \\
\hline Canada* & CAN & 2000 & 2.663 & 2.214 & 2.562 & 2.356 \\
\hline Chile* & $\mathrm{CHL}$ & 2000 & 2.962 & 2.805 & 2.673 & 2.824 \\
\hline China & $\mathrm{CHN}$ & 2001 & 3.111 & 2.867 & 3.220 & 2.186 \\
\hline Colombia & $\mathrm{COL}$ & $1997-98$ & 2.968 & 3.154 & 3.139 & \\
\hline Croatia & HRV & 1999 & 2.961 & 2.983 & 3.117 & 2.430 \\
\hline Czech Republic* & CZE & 1999 & 2.781 & 2.536 & 2.565 & 2.200 \\
\hline Denmark* & DNK & 1999 & & & 2.148 & 2.238 \\
\hline Dominican Republic & DOM & 1996 & 2.868 & 3.174 & 3.524 & 2.993 \\
\hline Egypt & EGY & 2000 & 2.051 & 2.871 & 2.778 & \\
\hline El Salvador & SLV & 1999 & 3.400 & 3.443 & 3.702 & 3.203 \\
\hline Estonia & EST & 1999 & 2.404 & 2.445 & 2.421 & 2.343 \\
\hline Finland* & FIN & 2000 & 2.583 & 2.086 & 2.456 & 2.230 \\
\hline France* & FRA & 1999 & 2.978 & 2.219 & 2.511 & 2.699 \\
\hline Georgia & GEO & 1996 & 2.645 & 3.056 & 2.747 & 2.416 \\
\hline Germany* & DEU & 1999 & & 2.284 & 2.704 & 2.181 \\
\hline Great Britain* & GBR & 1999 & 2.547 & 2.186 & 2.393 & 2.152 \\
\hline Greece* & GRC & 1999 & & & 2.581 & 2.535 \\
\hline Hungary* & HUN & 1999 & & & 2.839 & 2.545 \\
\hline Iceland* & ISL & 1999 & 2.845 & 2.119 & 2.641 & 1.855 \\
\hline Indonesia & IDN & 2001 & 2.328 & 2.635 & 3.102 & \\
\hline Iran & IRN & 2000 & 2.398 & 2.618 & 2.695 & \\
\hline Ireland* & IRL & 1999 & 2.749 & 2.276 & 2.540 & 2.290 \\
\hline Italy* & ITA & 1999 & 2.729 & 2.214 & 2.675 & 2.487 \\
\hline
\end{tabular}




\begin{tabular}{|c|c|c|c|c|c|c|}
\hline Japan* & JPN & 2000 & 2.201 & 1.851 & 2.589 & 2.068 \\
\hline Jordan & JOR & 2001 & 2.735 & 2.951 & 2.819 & \\
\hline Kyrgyzstan & KGZ & 2003 & 3.051 & 3.186 & 3.225 & 2.842 \\
\hline Latvia & LVA & 1999 & & & 2.665 & 2.287 \\
\hline Lithuania* & LTU & 1999 & 3.075 & 2.891 & 2.830 & 2.698 \\
\hline Luxembourg* & LUX & 1999 & 2.606 & & 2.468 & 2.484 \\
\hline Macedonia & MKD & 2001 & 3.023 & 2.877 & 2.879 & 2.536 \\
\hline Malta* & MLT & 1999 & & & 2.759 & 2.086 \\
\hline Mexico & MEX & 2000 & 3.606 & 3.306 & 3.548 & 3.233 \\
\hline Moldova & MDA & 2002 & 2.635 & 2.764 & 2.692 & 2.562 \\
\hline Morocco & MAR & 2001 & 3.099 & 3.508 & 3.264 & 2.212 \\
\hline Netherlands* & NLD & 1999 & 2.025 & 1.860 & 2.111 & 2.044 \\
\hline New Zealand* & NZL & 1998 & 2.628 & 2.269 & 2.701 & 2.261 \\
\hline Nigeria & NGA & 2000 & 2.877 & & 2.866 & \\
\hline Norway* & NOR & 1996 & 2.264 & 1.906 & 2.344 & 1.902 \\
\hline Pakistan & PAK & 2001 & 2.151 & 1.647 & 1.917 & \\
\hline Peru & PER & 2001 & 2.806 & 2.861 & 3.224 & 2.768 \\
\hline Philippines & PHL & 2001 & 2.716 & 2.679 & 2.915 & 2.490 \\
\hline Poland* & POL & 1999 & 3.183 & 2.834 & 2.617 & 2.761 \\
\hline Portugal* & PRT & 1999 & & 2.356 & 2.727 & 2.658 \\
\hline Romania & ROM & 1999 & 3.042 & 3.233 & 3.234 & 2.318 \\
\hline Russia & RUS & 1999 & 3.006 & 2.763 & 2.905 & 2.692 \\
\hline Singapore & SGP & 2002 & 2.305 & 2.444 & 2.675 & 2.067 \\
\hline Slovakia* & SVK & 1999 & & & 2.611 & 2.232 \\
\hline Slovenia* & SVN & 1999 & 2.689 & & 2.655 & 2.279 \\
\hline South Africa* & ZAF & 2001 & 3.120 & 3.060 & 3.114 & 2.532 \\
\hline South Korea & KOR & 2001 & 2.747 & 2.386 & 2.271 & 2.239 \\
\hline Spain* & ESP & 1999-00 & 2.858 & 2.494 & 2.505 & 2.350 \\
\hline Sweden* & SWE & 1999 & & & 2.221 & 1.924 \\
\hline Switzerland* & CHE & 1996 & 3.073 & 2.381 & 2.719 & 2.356 \\
\hline Tanzania & TZA & 2001 & 3.834 & 3.836 & 3.319 & 3.137 \\
\hline Turkey & TUR & 2001 & 3.248 & 3.298 & 3.267 & 3.093 \\
\hline USA* & USA & 1999 & 2.567 & 2.239 & 2.697 & 2.396 \\
\hline Uganda & UGA & 2001 & 3.182 & 3.016 & 3.104 & 2.310 \\
\hline Ukraine & UKR & 1999 & 2.981 & 2.975 & 2.998 & 2.971 \\
\hline Uruguay* & URY & 1996 & 3.250 & 2.718 & 2.861 & 2.869 \\
\hline Venezuela & VEN & 2000 & 3.442 & 3.309 & 3.460 & 3.015 \\
\hline Vietnam & VNM & 2001 & 3.055 & 2.858 & 2.935 & 2.638 \\
\hline Zimbabwe & ZWE & 2001 & 3.436 & 3.431 & 3.318 & 2.623 \\
\hline
\end{tabular}




\begin{tabular}{|c|c|c|}
\hline \multicolumn{2}{|c|}{ Table A2. Dependent and control variables } & $\mathbf{N}$ \\
\hline \multicolumn{3}{|l|}{ Dependent variables } \\
\hline GOVTRANSSUB & $\begin{array}{l}\text { General government transfers and subsidies as a percentage of GDP. } \\
\text { Average for 2003, } 2004 \text { and 2005. Source: Gwartney and Lawson } \\
(2008) \text {. }\end{array}$ & 69 \\
\hline GOVCONS & $\begin{array}{l}\text { General government consumption as a percentage of total consumption. } \\
\text { Average for 2003, } 2004 \text { and 2005. Source: Gwartney and Lawson } \\
(2008) \text {. }\end{array}$ & 74 \\
\hline \multicolumn{3}{|c|}{ Basic control variables } \\
\hline AFRICA & $\begin{array}{l}\text { Dummy equal to } 1 \text { if the country is in Africa. Source: Persson \& } \\
\text { Tabellini (2003) and own classification. }\end{array}$ & 74 \\
\hline ASIAE & $\begin{array}{l}\text { Dummy equal to } 1 \text { if the country is in Southern or Eastern Asia. Source: } \\
\text { Persson \& Tabellini (2003) and own classification. }\end{array}$ & 74 \\
\hline LAAM & $\begin{array}{l}\text { Dummy equal to } 1 \text { if the country is in Latin America, Central America } \\
\text { or Carribean, Source: Persson \& Tabellini (2003) and own classification. }\end{array}$ & 74 \\
\hline COL_ESPA & $\begin{array}{l}\text { Spanish colonial origin weighted by the number of years between } \\
\text { independence and } 1998 \text {. The variable takes on the value }(250-t) / 250 \text { for } \\
\text { countries with Spanish colonial origin (where } t \text { is the years of } \\
\text { independence) and zero for other countries. Source: Persson \& Tabellini } \\
(2003) \text {. }\end{array}$ & 74 \\
\hline COL_UKA & $\begin{array}{l}\text { British colonial origin weighted by the number of years of independence } \\
\text { (see COL_ESPA). Source: Persson \& Tabellini (2003). }\end{array}$ & 74 \\
\hline COL_OTHA & $\begin{array}{l}\text { Other colonial origin weighted by the number of years of independence } \\
\text { (see COL_ESPA). Source: Persson \& Tabellini (2003). }\end{array}$ & 74 \\
\hline LYP & $\begin{array}{l}\text { Natural logarithm of real GDP per capita in constant } 2000 \text { dollars in } \\
\text { year } 2000 \text { (2001 for Singapore). Source: World Bank (2009). }\end{array}$ & 74 \\
\hline TRADE & $\begin{array}{l}\text { Sum of exports and imports as a share of GDP in } 2000 \text { (2001 for } \\
\text { Singapore). Source: World Bank (2009). }\end{array}$ & 74 \\
\hline PROP1564 & $\begin{array}{l}\text { Proportion of population aged } 15 \text { to } 64 \text { in } 2000 \text {. Source: World Bank } \\
\text { (2009). }\end{array}$ & 74 \\
\hline PROP65 & $\begin{array}{l}\text { Proportion of population aged } 65 \text { or older in 2000. Source: World Bank } \\
\text { (2009). }\end{array}$ & 74 \\
\hline FEDERAL & $\begin{array}{l}\text { Dummy equal to } 1 \text { if the country has a federal political structure. } \\
\text { Source: Persson \& Tabellini (2003) and Adserà et al (2003). }\end{array}$ & 74 \\
\hline OECD & $\begin{array}{l}\text { Dummy equal to } 1 \text { if the country was an OECD member before } 1993 \\
\text { (excluding Turkey). Source Persson \& Tabellini (2003) and OECD. }\end{array}$ & 74 \\
\hline \multicolumn{3}{|c|}{ Additional variables (ordered according to appearance in the text) } \\
\hline DEMOC & $\begin{array}{l}\text { Index of the level of institutionalized democracy in } 2000 \text {. Scale from } 0 \\
\text { to } 10 \text { where } 10 \text { indicates the highest level of democracy. Source: } \\
\text { Marshall and Jaggers (2007). }\end{array}$ & 69 \\
\hline POLITY & $\begin{array}{l}\text { Index of institutionalized democracy/autocracy in } 2000 \text {. Scale from }-10 \\
\text { to } 10 \text {, where } 10 \text { is the highest level of democracy (and the lowest level } \\
\text { of autocracy). Source: Marshall and Jaggers (2007). }\end{array}$ & 69 \\
\hline MOUNTAIN & $\begin{array}{l}\text { Percent mountainous terrain. Source: Fearon \& Laitin (2003) who build } \\
\text { on the work by geographer A. J. Gerard for the World Bank. }\end{array}$ & 69 \\
\hline LATITUDE & $\begin{array}{l}\text { The absolute value of the latitude of the country, scaled to take values } \\
\text { between } 0 \text { and } 1 \text {. Source: Teorell et al. (2008) which in turn obtained the } \\
\text { data from La Porta et al. (1999). }\end{array}$ & 74 \\
\hline
\end{tabular}




\begin{tabular}{|c|c|c|}
\hline AREA & $\begin{array}{l}\text { Logarithm of total surface area measured in square kilometers. Source: } \\
\text { World Bank (2009). }\end{array}$ & 74 \\
\hline LOGPOP & Logarithm of total population in 2000. Source: World Bank (2009). & 74 \\
\hline POPDENS & $\begin{array}{l}\text { Population density (people per sq. km) in 2000. Source: World Bank } \\
(2009) \text {. }\end{array}$ & 74 \\
\hline ETHFRAC & $\begin{array}{l}\text { Ethnic fractionalization. Reflects the probability that two randomly } \\
\text { selected individuals belong to the same ethnic group. This is calculated } \\
\text { as one minus the sum of squared shares of each group and therefore } \\
\text { takes values between } 0 \text { and } 1 \text {. Source: Alesina et al. (2003). }\end{array}$ & 74 \\
\hline RELFRAC & $\begin{array}{l}\text { Religious fractionalization measured in the same way as ETHFRAC. } \\
\text { Source: Alesina et al. (2003). }\end{array}$ & 74 \\
\hline LINGFRAC & $\begin{array}{l}\text { Linguistic fractionalization measured in the same way as ETHFRAC. } \\
\text { Source: Alesina et al. (2003). }\end{array}$ & 73 \\
\hline TRUST & $\begin{array}{l}\text { Average (binary) response from WVS (code a165) collected in the year } \\
\text { listed in Table A1. Source: European Values Study Group and World } \\
\text { Values Association (2006). }\end{array}$ & 74 \\
\hline PRES & $\begin{array}{l}\text { Dummy variable equal to } 1 \text { if the country had a presidential regime in } \\
2000 \text {. The original variable takes the values of } 0,1 \text { and } 2 \text {. We classify } \\
\text { countries with values } 1 \text { and } 2 \text { as "parliamentary" and those with zero as } \\
\text { "presidential". Source: Beck et al. (2001). }\end{array}$ & 73 \\
\hline MAJ & $\begin{array}{l}\text { Dummy equal to } 1 \text { if elections are based on plurality rule in } 2000,0 \\
\text { otherwise. Source: Beck et al. (2001). }\end{array}$ & 71 \\
\hline GINI & $\begin{array}{l}\text { Estimates of the Gini index based on primary household survey data } \\
\text { obtained from government statistical agencies and World Bank country } \\
\text { departments. Data for high-income economies is from the Luxembourg } \\
\text { Income Study database. Data refers to various years between } 1995 \text { and } \\
2005 \text { and the observation closest to the year } 2000 \text { has been used. Source: } \\
\text { World Bank (2009). }\end{array}$ & 70 \\
\hline PROPRESP & $\begin{array}{l}\text { Proportion of respondents in WVS that did not respond to the survey } \\
\text { question or said that they did not have an answer. There is one variable } \\
\text { for each of the four questions EQUALITY, PRIVATE, GOV and } \\
\text { COMP. Source: European Values Study Group and World Values } \\
\text { Association (2006). }\end{array}$ & $62-74$ \\
\hline COHERENCE & $\begin{array}{l}\text { For each of the four questions EQUALITY, PRIVATE, GOV and } \\
\text { COMP, this variable is the average of the absolute correlation of } \\
\text { individual responses with the three other questions calculated for each } \\
\text { country. Source: European Values Study Group and World Values } \\
\text { Association (2006). }\end{array}$ & 53 \\
\hline PFREEDOM & $\begin{array}{l}\text { Press freedom index in } 2002 \text { ranging from } 0 \text { (total press freedom) and } \\
100 \text { (no press freedom). Source: Teorell et al. (2008), which obtained } \\
\text { the data from Reporters Sans Frontières. }\end{array}$ & 60 \\
\hline CONFIDENCE & $\begin{array}{l}\text { The average response to the question about the confidence in the } \\
\text { parliament from WVS (code e } 075 \text { ) collected in the year listed in Table } \\
\text { A1. Responses range from } 1 \text { ("A great deal") to } 4 \text { ("None at all"). } \\
\text { Source: European Values Study Group and World Values Association } \\
\text { (2006) }\end{array}$ & 73 \\
\hline CORRUPTION & $\begin{array}{l}\text { Transparency International's index of corruption in the public sector } \\
\text { ranging from } 0 \text { (highly corrupt) to } 10 \text { (highly clean). Source: Teorell et } \\
\text { al. (2008). }\end{array}$ & 67 \\
\hline CONSENSUS & $\begin{array}{l}\text { This is the distance between the average response and } 5.5 \text { for each of the } \\
\text { four questions EQUALITY, PRIVATE, GOV and COMP. }\end{array}$ & $62-74$ \\
\hline
\end{tabular}


GOD

PRIDE

AUTHORITY

ABORT

HOMO

TURNOUT

MAJSEATS

PRIGHTS

HERFGOV

HERFLEG

GOVPOL
Question about how important god is in the respondent's life from WVS (code f063) collected in the year listed in Table A1. Responses range from 1 ("Not at all important") to 10 ("Very important"). Source: European Values Study Group and World Values Association (2006)

Question about how proud the respondent is of his/her nationality from WVS (code g006) collected in the year listed in Table A1. Responses range from 1 ("Very proud") to 4 ("Not at all proud"). Source: European Values Study Group and World Values Association (2006)

Question about whether respondent would like to see a change toward "greater respect for authority" from WVS (code e018) collected in the year listed in Table A1. Responses range from 1 ("Good thing") to 3 ("Bad thing"'). Source: European Values Study Group and World Values Association (2006).

Question about whether abortion is justifiable from WVS (code f120) collected in the year listed in Table A1. Responses range from 1 ("Never justifiable") to 3 ("Always justifiable"). Source: European Values Study Group and World Values Association (2006).

Question about whether homosexuality is justifiable from WVS (code f118) collected in the year listed in Table A1. Responses range from 1 ("Never justifiable") to 3 ("Always justifiable"). Source: European Values Study Group and World Values Association (2006).

Turnout in the most recent parliamentary election prior to 2002 measured as the total number of votes cast divided by the number of registered voters (RV). Source: Teorell et al. (2008), who obtained the data from the International Institute for Democracy and Electoral Assistance.

Fraction of seats in the parliament that was held by the government in 2000. Source: Beck et al. (2001).

Heritage Foundation's property rights score ranging from 0 and 100 , where 100 is the maximum degree of protection of property rights. Source: Teorell et al. (2008).

Herfindahl index: government. The sum of the squared seat shares of all parties in the government. Data for 2000. Source: Beck et al. (2001).

Herfindahl index: legislature. The sum of the squared seat shares of all parties in the legislature. Data for 2000. Source: Beck et al. (2001).

Polarization in government. The maximum distance between the chief executive's party ideology and the three largest government parties and legislature and the largest opposition party. Scale: 0 to 2. Data for 2000. Source: Keefer and David Stasavage (2003), but data has been obtained from the data set compiled by Beck et al. (2001). 